\title{
Numerical study on the response of the largest lake in China to climate change
}

\author{
Dongsheng $\mathrm{Su}^{1,2}$, Xiuqing $\mathrm{Hu}^{3}$, Lijuan Wen ${ }^{1}$, Shihua Lyu ${ }^{1,5}$, Xiaoqing Gao ${ }^{1}$, Lin Zhao ${ }^{1}$, Zhaoguo Li ${ }^{1}$, Juan Du ${ }^{1,2}$, and \\ Georgiy Kirillin ${ }^{4}$ \\ ${ }^{1}$ Key Laboratory of Land Surface Process and Climate Change in Cold and Arid Regions, Northwest Institute \\ of Eco-Environment and Resources, Chinese Academy of Sciences, 730000 Lanzhou, China \\ ${ }^{2}$ University of Chinese Academy of Sciences, 100049 Beijing, China \\ ${ }^{3}$ Key Laboratory of Radiometric Calibration and Validation for Environmental Satellites, National Satellite Meteorological \\ Center, China Meteorological Administration, 100081 Beijing, China \\ ${ }^{4}$ Department of Ecohydrology, Leibniz-Institute of Freshwater Ecology and Inland Fisheries (IGB), 12587 Berlin, Germany \\ ${ }^{5}$ Plateau Atmosphere and Environment Key Laboratory of Sichuan Province, School of Atmospheric Sciences, Chengdu \\ University of Information Technology, 610225 Chengdu, China
}

Correspondence: Lijuan Wen (wlj@lzb.ac.cn)

Received: 28 November 2018 - Discussion started: 13 December 2018

Revised: 23 March 2019 - Accepted: 26 March 2019 - Published: 26 April 2019

Abstract. Lakes are sensitive indicators of climate change. There are thousands of lakes on the Tibetan Plateau (TP), and more than 1200 of them have an area larger than $1 \mathrm{~km}^{2}$; they respond quickly to climate change, but few observation data of lakes are available. Therefore, the thermal condition of the plateau lakes under the background of climate warming remains poorly understood. In this study, the China regional surface meteorological feature dataset developed by the Institute of Tibetan Plateau Research, Chinese Academy of Sciences (ITPCAS), MODIS lake surface temperature (LST) data and buoy observation data were used to evaluate the performance of lake model FLake, extended by simple parameterizations of the salinity effect, for brackish lake and to reveal the response of thermal conditions, radiation and heat balance of Qinghai Lake to the recent climate change. The results demonstrated that the FLake has good ability in capturing the seasonal variations in the lake surface temperature and the internal thermal structure of Qinghai Lake. The simulated lake surface temperature showed an increasing trend from 1979 to 2012, positively correlated with the air temperature and the downward longwave radiation while negatively correlated with the wind speed and downward shortwave radiation. The simulated internal thermodynamic structure revealed that Qinghai Lake is a dimictic lake with two overturn periods occurring in late spring and late autumn. The sur- face and mean water temperatures of the lake significantly increased from 1979 to 2012, while the bottom temperatures showed no significant trend, even decreasing slightly from 1989 to 2012. The warming was the strongest in winter for both the lake surface and air temperature. With the warming of the climate, the later ice-on and earlier ice-off trend was simulated in the lake, significantly influencing the interannual and seasonal variability in radiation and heat flux. The annual average net shortwave radiation and latent heat flux (LH) both increase obviously while the net longwave radiation and sensible heat flux ( $\mathrm{SH})$ decrease slightly. Earlier ice-off leads to more energy absorption mainly in the form of shortwave radiation during the thawing period, and later ice-on leads to more energy release in the form of longwave radiation, $\mathrm{SH}$ and $\mathrm{LH}$ during the ice formation period. Meanwhile, the lake-air temperature difference increased in both periods due to shortening ice duration.

\section{Introduction}

The Tibetan Plateau (TP) is the highest plateau in the world, known as the Earth's "third pole" (Qiu, 2008), and exerts a significant influence on regional and global atmospheric circulation through its dynamic and thermodynamic effects 
(Yanai et al., 1992; Duan and Wu, 2005). The TP is also one of the most sensitive regions to climate change: the surface air temperature increase over the TP due to global warming is stronger than in other regions (Guo and Wang, 2012; Duan and Xiao, 2015). Apart from warming, an increase in air humidity and precipitation and a decrease in shortwave radiation and wind speeds were reported for the central TP since the beginning of the 1980s (Liao et al., 2013; Yang et al., 2014). Thousands of lakes are scattered across the TP, accounting for $39.2 \%$ of the entire number and for $51.4 \%$ of the entire area of Chinese lakes (Ma et al., 2011). Lakes are inherit components of the hydrological system of the TP, named "the world water tower" (Xu et al., 2008), contributing essentially to the water cycle between atmosphere, glaciers and the major Asian rivers. Due to the significant increase in precipitation and melting of glaciers caused by climate change, the total area of lakes on the TP has tended to expand significantly since the late 1990s (Liao et al., 2013; Lei et al., 2014).

Large lake areas significantly influence the local and regional weather and climate, mainly because of their differences in albedo, heat capacity, roughness and energy exchange compared to the land surfaces around (Bonan et al., 1995; Eerola et al., 2010). Lakes are very sensitive to climate, and their physical, chemical and biological properties respond rapidly to a climate-related change (Adrian et al., 2009; Williamson et al., 2009). The surface water warming rates of lakes are mainly driven by the increasing air temperature (Adrian et al., 2009; Schmid et al., 2014), depending on combinations of climate and local characteristics that are associated with interactions among different climatic factors. Surface water is warming in many lakes around the globe, whereas some lakes are cooling or do not reveal any significant temperature trends (O'Reilly et al., 2015). Global warming also has an impact on the vertical thermal structure of lakes and causes mixing regime shifting (Livingstone, 2003, 2008; Boehrer and Schultze, 2008). Surface warming increases the summer vertical stability and prevents the heat transfer to the bottom of the lake so that a counter-trend of cooling may occur at the bottom (Kirillin et al., 2010). Warming also may result in drastic shifts in the date of lake ice break-up and freeze-up (Weyhenmeyer et al., 2004), which can significantly influence the seasonal thermal and energy regimes of the lakes (Rouse et al., 2003). The ice-on and ice break-up dates on lakes and rivers demonstrate a long-term trend in later freezing and earlier break-up around the Northern Hemisphere as a response to the increase in air temperature of about $1.2^{\circ} \mathrm{C}$ per 100 years (Magnuson et al., 2000).

Being similar to global trends, both warming and cooling trends occurred in the lakes on the TP (Zhang et al., 2014a). Due to the high elevation and low atmospheric density over the TP, the surface received solar radiation input is larger than in lowland areas, which results in large diurnal amplitudes of surface temperature (Gao et al., 1981; Ma et al., 2009). During the last decades, a negative trend in the solar radiation flux was observed over the TP, which can be ascribed to the increase in the air humidity (Shen et al., 2015). As a result, lakes are predicted to experience a cooling trend despite a significant increase in the air temperature over the plateau (Kirillin et al., 2017) that demonstrates decoupling of the air and land response to the global change and suggests a nonlinear response of the entire hydrological system.

Only a few observation data are available for TP lakes due to the harsh environmental conditions; therefore, the lake thermal conditions and their response to climate change are not understood well. Hence, numerical simulation appears to be the most efficient approach in lake investigation on the TP, provided that the numerical model is calibrated well and reliable information on the atmospheric forcing is available.

In this paper, we model the brackish endorheic Qinghai Lake - the largest lake on the TP and in China - to reveal the major features of the TP lake response to climate change by using the lake model FLake (Mironov, 2008). FLake is a highly parameterized one-dimensional lake model aimed primarily at lake representation in land schemes of regional climate models. The model was numerously tested before for different lakes worldwide (Kirillin, 2010; Bernhardt et al., 2012; Stepanenko et al., 2013; Thiery et al., 2014), including freshwater lakes (Kirillin et al., 2017) and a brackish lake (Lazhu et al., 2016) on the TP. The strength of FLake is its high computational efficiency combined with a realistic representation of the major physics, which made the model a basic tool for lake representation in the land schemes on the global scale (e.g. Dutra et al., 2010; Salgado and Le Moigne, 2010; Rooney and Bornemann, 2013; Mallard et al., 2014). However, FLake is originally a freshwater lake model that does not account for salinity effects on mixing and heat exchange with the atmosphere. Saline and brackish lakes represent most of the inland water bodies on the TP, and they may have an appreciable effect on the land-atmosphere interaction. Therefore, in addition to quantifying the recent climate change effects on the thermal regime of China's largest lake, the second aim of the study is to test the FLake performance on brackish lakes after parameterizations of the salinity effect on the temperature of maximum density and freezing point in the model. Here, we applied the freshwater lake model to a brackish TP lake in order to (i) evaluate the ability of the lake model FLake to simulate the main thermodynamic features of the lake in high-altitude conditions and (ii) validate the performance of a freshwater lake model, extended by simple parameterizations of salinity effects, for a brackish lake.

\section{Study area, data and methodology}

\subsection{Study area}

Qinghai Lake $\left(36^{\circ} 32^{\prime}-37^{\circ} 15^{\prime} \mathrm{N}, 99^{\circ} 36^{\prime}-100^{\circ} 47^{\prime} \mathrm{E}\right)$ is the largest inland lake in China, with a surface area of $4497 \mathrm{~km}^{2}$ (in 2017) and a catchment area of $29660 \mathrm{~km}^{2}$. The maxi- 


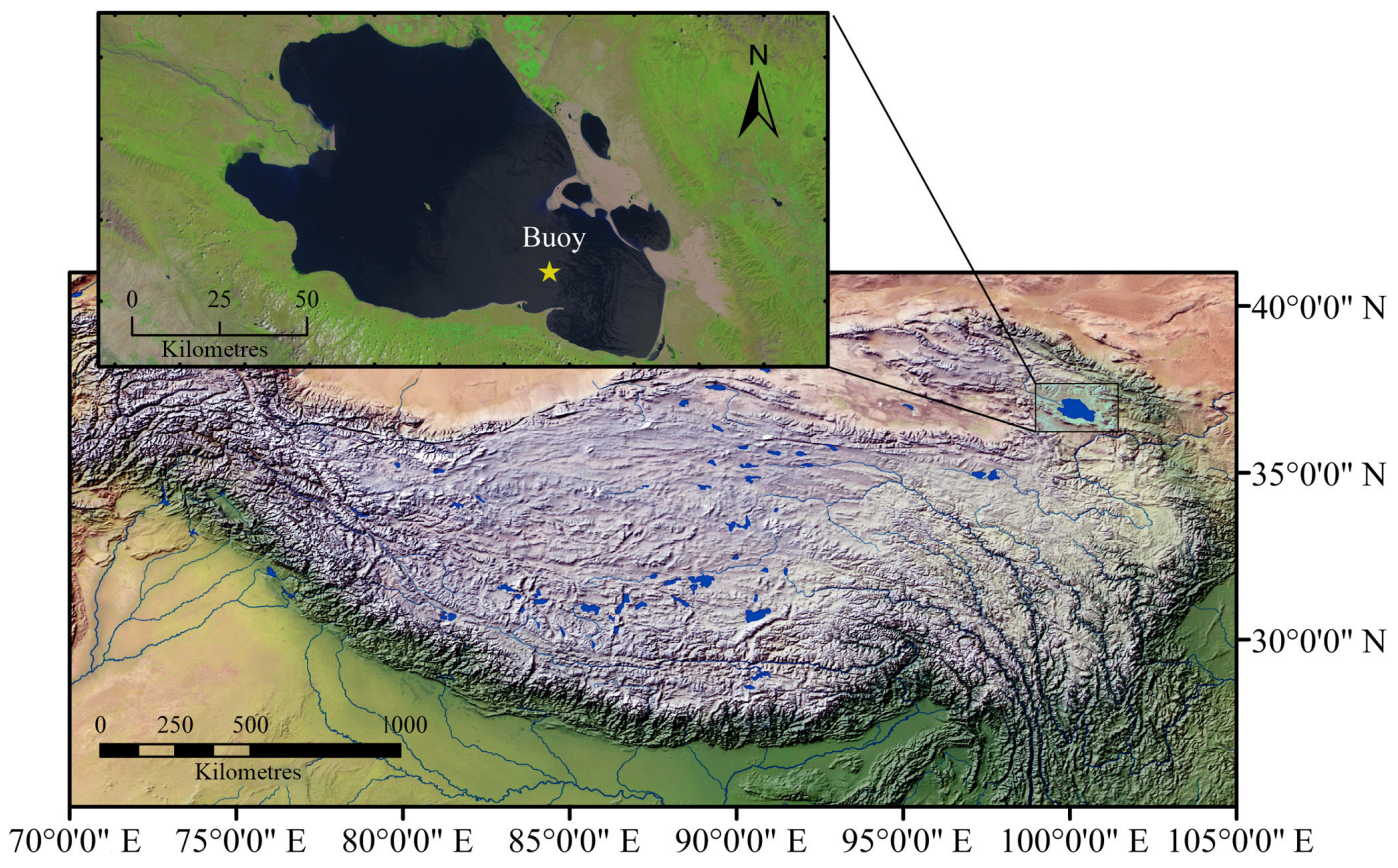

Figure 1. Study area and the location of the buoy station.

mum length and width of the lake are approximately 106 and $67 \mathrm{~km}$, respectively. It is an endorheic, brackish lake (salinity $12.5 \mathrm{~g} \mathrm{~L}^{-1}, \mathrm{pH}$ 9.3; Deng et al., 2010) located on the northeastern margin of the TP (Fig. 1) at the height of about $3194 \mathrm{~m}$ a.s.l. The mean and maximum depths of the lake are 21 and $32.8 \mathrm{~m}$, respectively. The lake is ice-covered from December-January to early April; the average annual lake water temperature is $5.4^{\circ} \mathrm{C}$, with the maximum monthly temperature of $17.2^{\circ} \mathrm{C}$ (August) and the minimum of $-2.0^{\circ} \mathrm{C}$ (January; Li et al., 2016). The average annual air temperature (1959-2015) at the lake is $1.9^{\circ} \mathrm{C}$. The mean annual precipitation in 1959-2015 was about $340 \mathrm{~mm}$ (Ding et al., 2018), with more than $65 \%$ occurring in summer. Annual evaporation from the lake surface was $924 \mathrm{~mm}$, and surface runoff water inflow and groundwater inflow were 348 and $138 \mathrm{~mm}$, respectively (Li et al., 2007).

Qinghai Lake is sensitive to climate variability. Because the evaporation was generally larger than river runoff and precipitation from 1961 to 2004, the water level of Qinghai Lake decreased at an average rate of $7.6 \mathrm{~cm}$ per year (Cui and $\mathrm{Li}, 2016)$. However, the precipitation continuously increased in $1970-2015$ by $15.603 \mathrm{~mm}$ per decade, according to the data from the Gangcha station (the nearest meteorological station approximately $13 \mathrm{~km}$ north to Qinghai Lake). Simultaneously, the runoff from the melting of Qilian Mountain glaciers was also increasing because of the regional warming trend of $0.319^{\circ} \mathrm{C}$ per decade, coupled with the decreasing evaporation by $1.343 \mathrm{~mm}$ per year (observed by Gangcha station) during 1970-2003 (Tang et al., 2018). Since 2004, as the runoff and precipitation exceeded evaporation and the re- gional climate gradually turned to the direction of "warm and humid", the Qinghai Lake level increased at a rate of $14 \mathrm{~cm}$ per year during 2004-2012 (Dong and Song, 2011; Zhang et al., 2011, 2014b; Cui et al., 2016).

\subsection{Data}

\subsubsection{Buoy observation data}

The observation data were obtained from the Qinghai Lake hydrological automatic meteorological observation buoy $\left(36.68^{\circ} \mathrm{N}, 100.50^{\circ} \mathrm{E}\right)$. The recorded parameters included air temperature, wind direction, wind speed, pressure, relative humidity, surface water temperature at $0.7 \mathrm{~m}$ below the surface, dew point temperature and water salinity. The observation period was confined to the summer and autumn openwater periods from 2001 to 2005 (Fig. 2), with an observation interval of $3 \mathrm{~h}$.

\subsubsection{MODIS lake surface temperature}

Some gaps in the long-term buoy observations were caused by harsh environmental conditions and the long ice cover period. Therefore, the $8 \mathrm{~d}$ MODIS lake surface temperature (LST) product (MOD11C2), which covers 2001-2012, was additionally used to evaluate the long-term simulated results. This product offers an $8 \mathrm{~d}$ combined radiative surface temperature at approximately 10:30 and 22:30 LT (local time), which is the satellite transit time, with a resolution of $5 \mathrm{~km}$ (Wan et al., 2004). Here we used a single point of MODIS LST closest to the buoy location in order to be comparable 


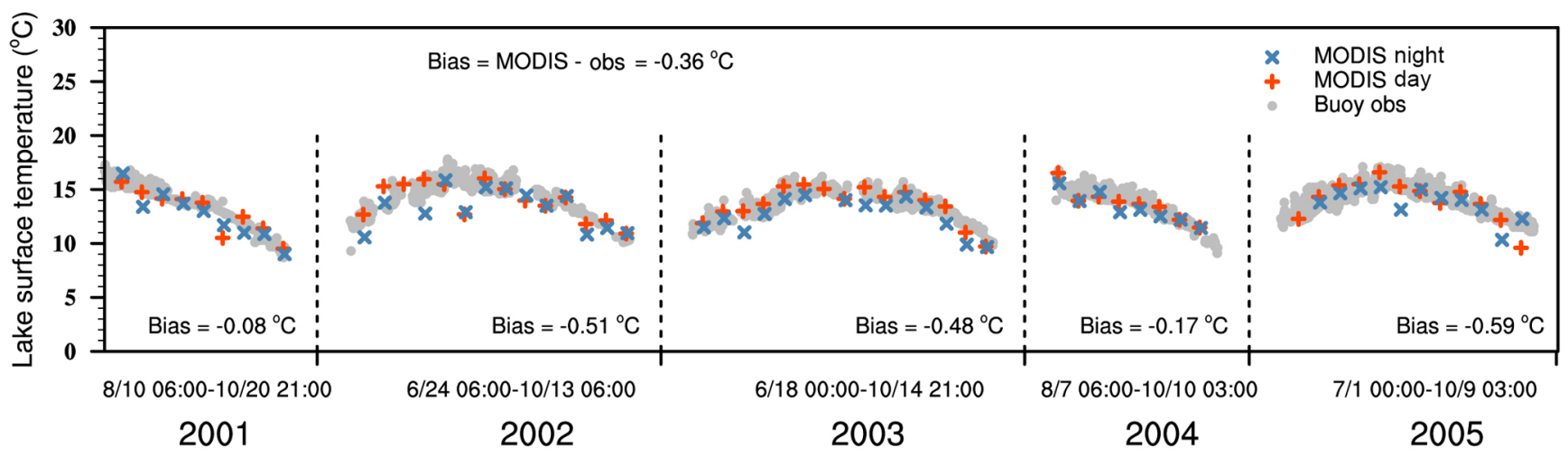

Figure 2. Comparison of the lake surface temperature between observations from buoy and MODIS.

with the buoy observed data. We removed a few abnormal values that might be influenced by cloud cover (Langer et al., 2010). The MODIS data comparison against the buoy data found them generally consistent, but MODIS LST was generally lower than buoy observations, with the 2001-2005 average bias of $-0.36^{\circ} \mathrm{C}$ (Fig. 2). The bias might be attributed to the cool skin phenomenon making the radiation temperature typically lower than the bulk temperatures (Robinson et al., 1984; Donlon et al., 2002; Minnett et al., 2003; Leppäranta and Lewis, 2007).

\subsubsection{Dataset of lake ice phenology in Qinghai Lake}

The dataset on lake ice phenology in Qinghai Lake from 2000 to 2018 was built by using RS and GIS technologies based on the Terra MODIS surface reflectance product and Landsat TM/ETM+/OLI remote sensing images (Qi et al., 2018). The dataset uses the method of threshold segmentation to extract the ice area of Qinghai Lake based on the MOD09GQ product by setting a reflectance threshold for the red band and a reflectance difference threshold between red and near-infrared bands. The extracted ice area was then validated against the visually interpreted ice area based on Landsat TM/ETM+/OLI images. The dataset includes ice-water vector boundary data, area ratio and phenological characters in Qinghai Lake from 2000 to 2018. Phenological information includes the start and end dates of lake freeze-up and break-up and ice cover duration. The dataset provides a reference for exploring the spatio-temporal characteristics of lake ice in Qinghai Lake as well as for estimating lake ice cover response to climate changes in the region.

\subsubsection{ITPCAS forcing data}

The China regional surface meteorological feature dataset (Yang et al., 2010) developed by the Institute of Tibetan Plateau Research, Chinese Academy of Sciences (hereafter ITPCAS), was used as atmospheric forcing data for the FLake model. The version used here covers the period of 1979-2012. It was produced by merging a variety of data sources, including Princeton meteorological forcing data, Global Land Data Assimilation System (GLDAS) data, the Global Energy and Water Cycle Experiment-Surface Radiation Budget (GEWEX-SRB) shortwave radiation dataset, Tropical Rainfall Measuring Mission (TRMM) satellite precipitation analysis data, and China Meteorological Administration (CMA) station data. The ITPCAS forcing dataset includes air temperature and specific humidity at $2 \mathrm{~m}$ height above the ground, wind speed at $10 \mathrm{~m}$ height, surface pressure, precipitation, and downward shortwave and longwave radiations at a spatial resolution of $0.1^{\circ}$ and a temporal resolution of $3 \mathrm{~h}$ (Chen et al., 2011). The downward longwave radiation was calculated by the model of Crawford and Duchon (1999) as a function of air temperature, pressure, specific humidity and downward shortwave radiation. ITPCAS forcing incorporates CMA station data; therefore, it is more accurate in this region of China compared with other datasets and is generally preferable for modelling studies in China (Chen et al., 2011; Guo and Wang, 2013; Liu and Xie, 2013).

\subsection{Lake model}

The FLake model (Mironov, 2008) is used to simulate the vertical temperature profile and the energy budget of the different layers of the lake on the timescales from several hours to many years. The model divides the lake water body vertically into two layers, the upper layer being the mixed layer with uniform temperature. Beneath the mixed layer, the temperature profile is parameterized using the concept of self-similarity (Kitaigorodskii and Miropolsky, 1970), which means that the characteristic shape of the temperature profile is conserved irrespective of the depth of this layer. The parameterization formula is

$$
\frac{\theta_{\mathrm{s}}(t)-\theta(z, t)}{\Delta \theta(t)}=\Phi_{\theta}(\zeta) \quad h(t) \leq z \leq D
$$

where $t$ is time, $z$ is the depth, $\theta_{\mathrm{S}}(t)$ is the temperature of the upper mixed layer of depth $h(t), \Delta \theta(t)=\theta_{\mathrm{S}}(t)-\theta_{\mathrm{b}}(t)$ 
is the temperature differences across the thermally stratified layer of the depth of $\Delta h(t)=D-h(t), D$ is the lake depth, and $\theta_{\mathrm{b}}(t)$ is the temperature at the lake bottom. $\Phi_{\theta}(\zeta)$ is a dimensionless "universal" function of the dimensionless depth $\zeta=\frac{z-h(t)}{\Delta h(t)}$ which satisfies the boundary conditions $\Phi_{\theta}(0)=0$ and $\Phi_{\theta}(1)=1$. Based on the self-similarity assumption, the temperature profile can be expressed as a twolayer approximation:

$\theta(t)=\left\{\begin{array}{ll}\theta_{\mathrm{s}}(t) & 0 \leq z \leq h(t) \\ \left.\theta_{\mathrm{s}}(t)-\left[\theta_{\mathrm{s}}(t)-\theta_{\mathrm{b}}(t)\right) \Phi_{\theta}(\zeta)\right] & h(t) \leq z \leq D\end{array}\right.$.

Substitution of Eq. (2) over the lake water column with subsequent substitution into the heat transport equation yields a set of ordinary differential equations, including the lake in form of the shape factor $C_{\theta}=\int_{0}^{1} \Phi_{\theta}(\zeta)$. The resulting equation system is complemented by an equation for evolution of the mixed layer depth $h(t)$, which is calculated based on the convective entrainment or relaxation-type equation in terms of wind mixing (see Mironov, 2008 for details).

The shape factor $C_{\theta}$ is parameterized by a relaxation formula:

$\frac{\mathrm{d} C_{\theta}}{\mathrm{d} t}=\operatorname{sign}\left(\frac{\mathrm{d} h(t)}{\mathrm{d} t}\right) \frac{C_{\theta}^{\max }-C_{\theta}^{\min }}{t_{\mathrm{rc}}} \quad C_{\theta}^{\min } \leq C_{\theta} \leq C_{\theta}^{\max }$,

where $t_{\mathrm{rc}}$ is the empirically estimated relaxation time or times of the temperature profile in the thermocline from one limiting curve to the other, following the change of sign in $\frac{\mathrm{d} h(t)}{\mathrm{d} t}$. $C_{\theta}^{\min }=0.5$ and $C_{\theta}^{\max }=0.8$ are the minimum and maximum values of the shape factor.

Additionally, FLake includes the representation of the thermal structure of the ice layer, snow layer and the thermally active upper layer of bottom sediments, all using the self-similarity concept. The snow module of FLake has not been comprehensively tested so far. Compared with other lake models, it is relatively easy to adjust FLake to a specific application due to a small number of lake parameters to be specified, the major ones being the lake depth and the optical characteristics of the lake water.

To partially account for salinity effects in a brackish lake, the freshwater equation of state used by FLake was adjusted by changing the temperature of maximum water density $\left(T_{\mathrm{m}}\right)$ and the freezing point temperature $\left(T_{\mathrm{f}}\right)$. The parameterization formula of $T_{\mathrm{m}}$ and $T_{\mathrm{f}}$ obtained from linear approximations of the empirical function of state of seawater (Caldwell, 1978; UNESCO, 1981) are

$T_{\mathrm{m}}\left[{ }^{\circ} \mathrm{C}\right]=3.98-0.216 S$,

$T_{\mathrm{f}}\left[{ }^{\circ} \mathrm{C}\right]=-0.055 S$,

where the $S$ is salinity taken in parts per thousand (\%o or $\mathrm{g} \mathrm{L}^{-1}$ ). For the salinity of $S=12.5 \mathrm{~g} \mathrm{~L}^{-1}$, which is the case of Qinghai Lake, the equation gives $T_{\mathrm{m}}=1.28^{\circ} \mathrm{C}$ and $T_{\mathrm{f}}=$ $-0.69^{\circ} \mathrm{C}$. In addition, the lake depth was set to the mean depth of Qinghai Lake $(21 \mathrm{~m})$. The simulation started at the beginning of the year in 1979. The forcing data of 1979 were used to drive the Flake model 10 iterations for a spinup. Then the actual modelling period started in 1979 and ended in 2012. The simulation duration was 34 years, with the simulation step of $3 \mathrm{~h}$. The model runs were performed using both the original freshwater equation of state and the brackish water approximation (Eqs. 4-5). Here we defined the simulation with original freshwater equation of state as a freshwater lake (FL) experiment and the simulation with the brackish water approximation as a saltwater lake (SL) experiment.

\section{Results}

\subsection{Simulated lake temperatures}

Introduction of salinity remarkably affected the ice regime but not the lake surface temperatures. Therefore, only the simulation results of the SL experiment are analysed in this subsection. Comparison of the simulated lake surface temperatures against MODIS LST (Fig. 3) demonstrated that the FLake model can nicely simulate the seasonal variations in the lake surface temperature: the correlation coefficient amounted to 0.93 . The simulated temperature was, however, generally higher than the MODIS LST, with a positive bias of $1.98^{\circ} \mathrm{C}$ and a root-mean-square error (RMSE) value of $3.97^{\circ} \mathrm{C}$ for the annual mean, except in springtime, when the simulated LST had a negative bias of $-0.74^{\circ} \mathrm{C}$ compared to MODIS LST.

In order to evaluate the effect of the forcing data deviation on the simulation results, we applied a correction to the ITPCAS forcing data. Since the buoy observations are mainly available from June to October, only forcing data for this period of the year were corrected. The air temperature was adjusted with the linear relationship $(y=0.76 x+3.27, x$ for ITPCAS and $y$ for buoy observations), and the wind speed was corrected by adding a constant bias of $1.19 \mathrm{~m} \mathrm{~s}^{-1}$ between the mean buoy observation and the mean ITPCAS data. After the correction, the bias and RMSE between simulated LST and MODIS LST were both reduced for the open-water period (from 2.85 and 3.71 to 2.82 and $3.58^{\circ} \mathrm{C}$, respectively), especially for the summer $\left(3.30\right.$ to $\left.1.60^{\circ} \mathrm{C}\right)$ and the autumn $\left(2.97\right.$ to $\left.1.06^{\circ} \mathrm{C}\right)$. Through the correction of the driving data, we found that the positive bias between simulated LST and satellite data can be partly explained by the differences in the forcing weather data measured over the lake and provided by the ITPCAS data. The remaining bias may be partly attributed to the cool skin effect in the LST sensed by MODIS.

The effect of salinity stratification on the lake mixing was not accounted for by the FLake model, assuming purely thermal stratification. The modelled seasonal stratification of Qinghai Lake corresponded to that of a dimictic lake (Fig. 4) with typical features of this type of mixing regime (Kirillin and Shatwell, 2016). Winter and summer stratified periods are divided by two short periods of full vertical mixing (over- 


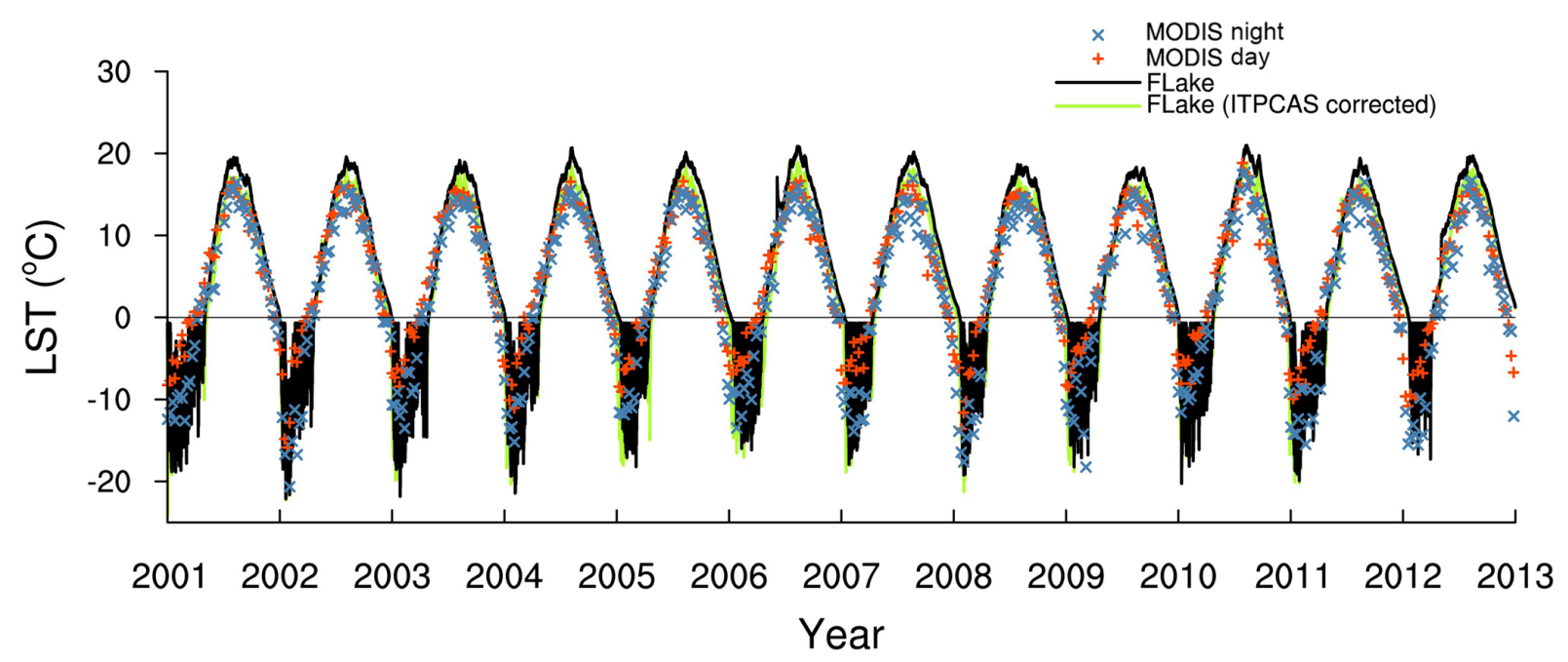

Figure 3. Comparison of lake surface temperature (LST) between FLake simulation forced by original (black line) and corrected (green line) ITPCAS data, and MODIS observation (cross markers).

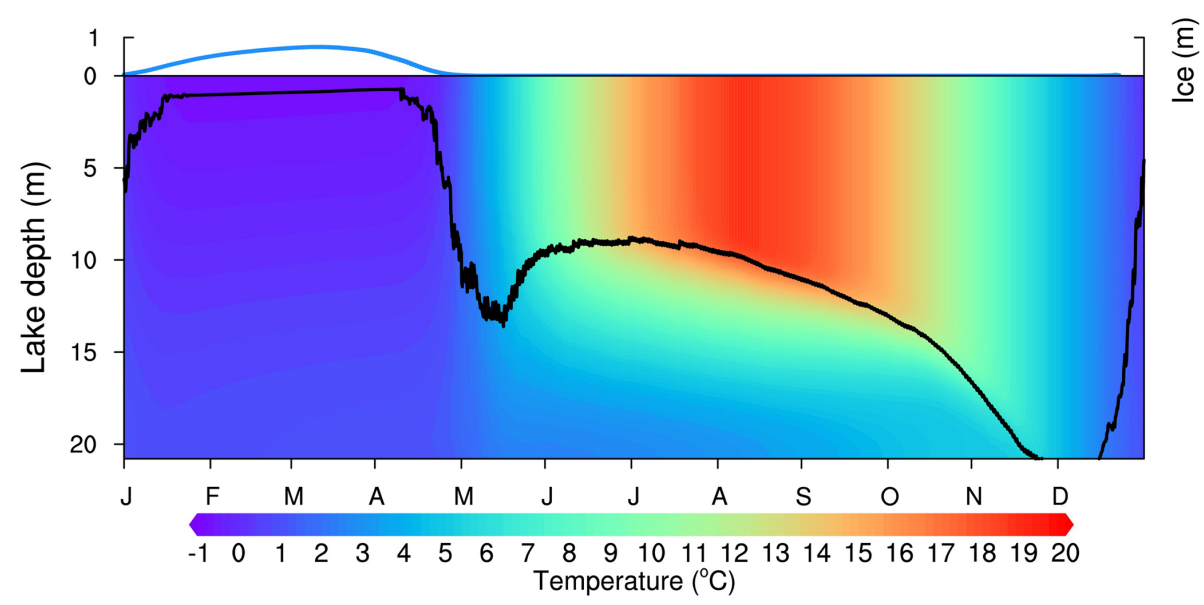

Figure 4. The modelled seasonal thermal stratification pattern and ice cover of Qinghai Lake averaged from 1979 to 2012 . The blue line is ice cover thickness, and the black one is the depth of the mixed layer.

turns) in late spring and late autumn. During the overturn period, dimictic lakes are supposed to be fully mixed with the bottom. From the simulation, we found that the spring overturn of Qinghai Lake, occurring around May, lasted for 2-3 weeks, and the depth of mixed layer reached the bottom of the lake in most but not all simulation years. The autumn overturn appeared around November-December, lasting approximately for a month, and the mixed layer reached the bottom of the lake in all simulated years. In the summer stratified period, the mixing process was mainly caused by the wind forcing and the stratification instability due to diurnal temperature variations, and the depth of the mixed layer reached $10-15 \mathrm{~m}$, gradually increasing with time.

Although the modelled LSTs are slightly lower in the spring and higher in other seasons, especially in summer and autumn, and the deviations in nighttime are larger than in daytime, the model simulated the variations in the LST and its typical magnitudes well and produced a reasonable vertical thermal structure.

\subsection{Response of lake thermal conditions to the long-term trends in external forcing}

According to the ITPCAS data from 1979-2012, the air temperature and longwave radiation had positive trends of $0.58^{\circ} \mathrm{C}(p<0.01)$ and $3.22 \mathrm{~W} \mathrm{~m}^{-2}(p<0.01)$ per decade, respectively, while the wind speed and shortwave radiation had negative trends of $-0.11 \mathrm{~m} \mathrm{~s}^{-1}(p>0.05)$ and $-2.41 \mathrm{~W} \mathrm{~m}^{-2}(p<0.05)$ per decade, respectively. These values are consistent with other reports on climate change over the TP. The air temperature at different weather stations on the TP is rising by an average of 0.09 to $0.74{ }^{\circ} \mathrm{C}$ per decade from 1961 to 2007 (Guo and Wang, 2012), while the wind 


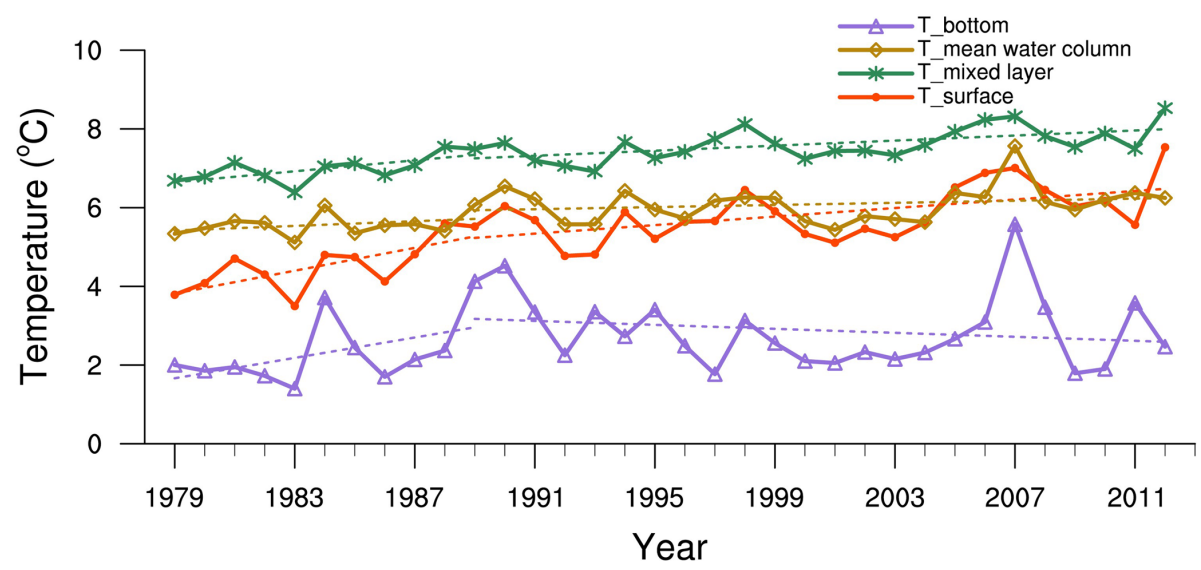

Figure 5. Annual variation trends of the lake water temperature at the surface, mixed layer, mean water column and bottom layer.

speed and shortwave radiation is decreasing (Yang et al., 2014).

From 1979 to 2012, the simulated LST, mixed-layer temperature and the lake mean temperature in the SL experiment was increasing at $0.74,0.38$ and $0.26^{\circ} \mathrm{C}$ per decade, respectively ( $p<0.01$ for all three trends); the bottom temperature revealed a slower trend at $0.2{ }^{\circ} \mathrm{C}$ per decade $(p>0.05$; Fig. 5). For the first decade from 1979 to 1989, all temperatures demonstrated a stronger warming trend, especially for the surface layer $\left(1.4{ }^{\circ} \mathrm{C}\right.$ per decade, $\left.p>0.05\right)$. Later on, the trend slowed down to $0.54{ }^{\circ} \mathrm{C}$ per decade $(p<0.05)$ for the surface temperature, same as the mixed layer $\left(0.32^{\circ} \mathrm{C}\right.$ per decade, $p<0.05)$ and mean water column $\left(0.14^{\circ} \mathrm{C}\right.$ per decade, $p>0.05$ ) during the rest of years. The bottom water temperature even demonstrated a slightly decreasing trend of $-0.25^{\circ} \mathrm{C}$ per decade $(p>0.05)$.

Due to the importance of the lake surface as an interface of heat and mass exchange between the lake and atmosphere, the relationship between the LST variation trend and main atmospheric characteristics was investigated (Fig. 6). The trend of LST simulated by FLake was consistent with rising air temperature $\left(0.58^{\circ} \mathrm{C}\right.$ per decade), but with a higher rate of $0.74{ }^{\circ} \mathrm{C}$ per decade. Meanwhile, the simulated LST had a positive correlation coefficient of $0.71(p<0.01)$ with air temperature. A negative correlation coefficient of -0.35 $(p<0.05)$ was found between the simulated LST and the wind speed. The downward shortwave radiation had a negative correlation coefficient of $-0.29(p>0.05)$ for the LST. The LST and the downward longwave radiation were positively correlated (coefficient of $0.74, p<0.01$ ).

\subsection{Lake ice cover}

Compared with the FL experiment, the salinity parameterization for $T_{\mathrm{m}}$ and $T_{\mathrm{f}}$ in the SL experiment has a certain effect on the ice phenology (Fig. 7): the maximum ice thickness is reduced, the freeze-up date is delayed and the break-up date is advanced, leading to a shorter ice duration period. Nev- ertheless, the interannual changes between them remained consistent. The simulated freeze-up and break-up date in the FL and SL experiments are both later than satellite observations, with some differences in interannual variations but a similar range in ice duration. In the SL experiment, the maximum ice thickness and the break-up date are closer to the observations; the former was reported at $0.7 \mathrm{~m}$ by Chen et al. (1995). Hence the ice phenology results from the SL experiment were used for further analysis.

The variations in break-up and freeze-up dates are sensitive to the meteorological conditions, e.g. air temperature, solar radiation and wind (Duguay et al., 2006; Latifovic and Pouliot, 2007; Ye et al., 2011; Kirillin et al., 2012; Yao et al., 2016). In the SL experiment, the simulated maximum ice thickness demonstrated a negative correlation of -0.52 $(p<0.01)$ to the mean air temperature anomaly from January to April in Qinghai Lake. With the increase in air temperature, the maximum ice thickness of Qinghai Lake reveals a decreasing trend of $-0.1 \mathrm{~m} \mathrm{decade}^{-1}(p<0.01$; Fig. 7a). Simulated ice cover of Qinghai Lake started in the late December to January and ended in early April to early May. The correlation coefficient of $-0.68(p<0.01)$ was found between the freeze-up date and mean air temperature anomaly for November-December (Fig. 7b), while a $0.48(p<0.01)$ correlation coefficient was found between a break-up date and mean temperature anomaly for March-April (Fig. 7c). With the increasing trend in the air temperature and LST, the freeze-up date was delayed by about $4.5(p<0.01)$ days every decade, and the break-up date advanced about $5.7 \mathrm{~d}$ $(p<0.01)$ earlier every decade, resulting in a shortening of the ice cover period by about $10.2 \mathrm{~d}(p<0.01)$ per decade (Fig. 7d).

\subsection{Interannual variation in energy balance}

Lake mean temperature is the indicator of the heat storage in the lake water body, whose changes are mainly driven by the heat exchange at the lake surface, which is composed of 

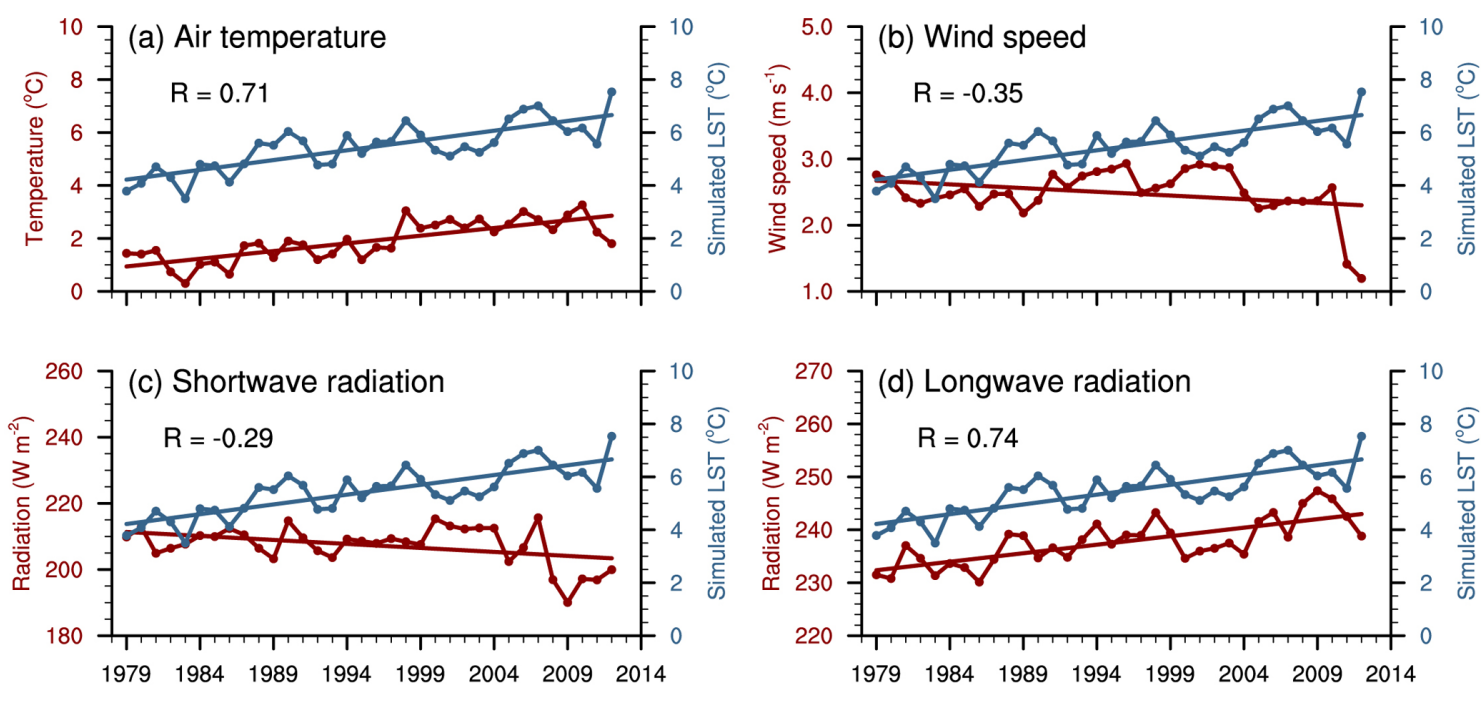

Year

Figure 6. Interannual variations in annual air temperature (a), wind speed (b), shortwave radiation (c) and longwave radiation (d) at Qinghai Lake, and their correlations with simulated annual mean lake surface temperature (LST) from 1979 to 2012.
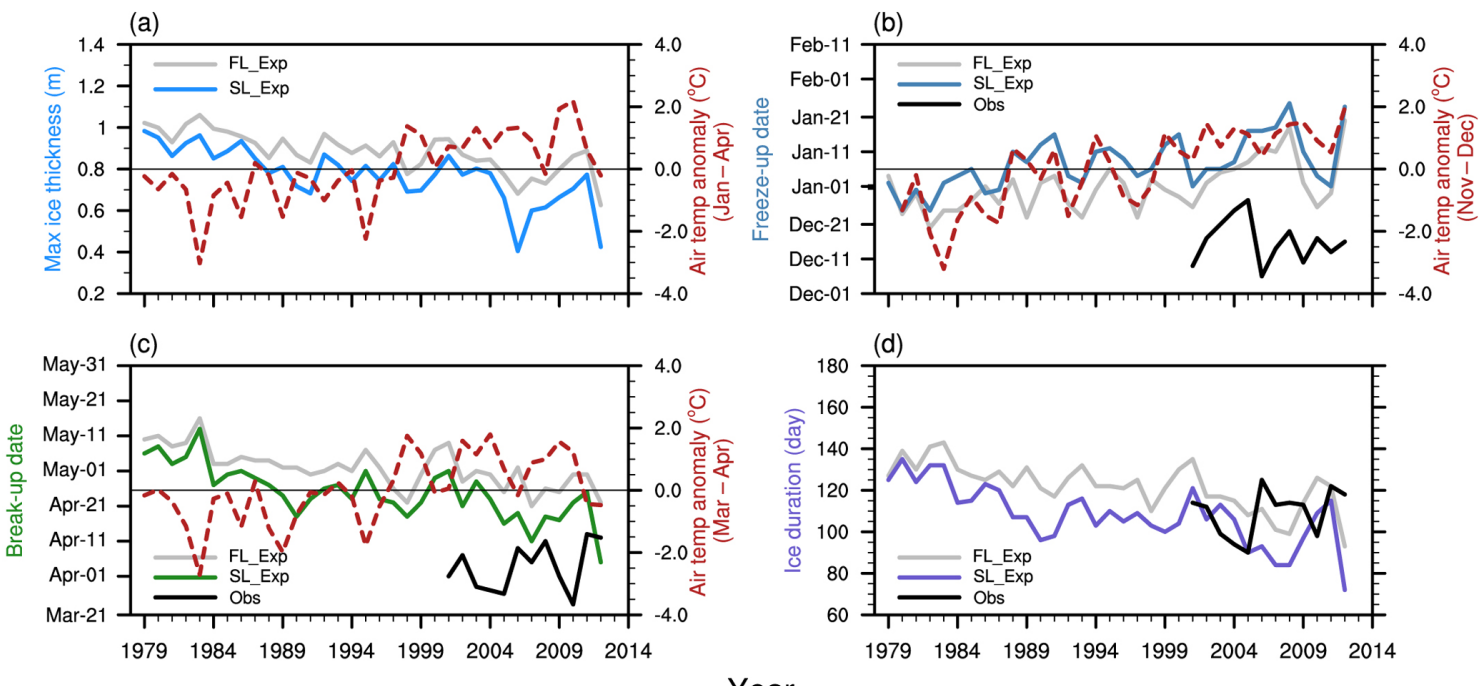

Year

Figure 7. The interannual variations in simulated annual maximum ice thickness (a), freeze-up date (b), break-up date (c) and ice duration (d) of Qinghai Lake. The coloured line indicates SL experiment, and the grey line indicates FL experiment. The red dashed line is air temperature anomaly in the specified period, and the black line is ice phenology observation derived from the satellite.

the net (shortwave and longwave) radiation budget, sensible heat flux (SH) and latent heat flux (LH). Quantification of the energy balance at the lake surface is necessary for understanding the mechanisms of the lake response to climate change. The heat transfer from precipitation, runoff and the bottom sediments of the lake are ignored here due to their small magnitudes and observational difficulties.

According to ITPCAS data, the solar radiation flux over Qinghai Lake was decreasing at $-2.41 \mathrm{~W} \mathrm{~m}^{-2}$ per decade $(p<0.05$; not shown), while simulation results produce a positive trend of $0.78 \mathrm{~W} \mathrm{~m}^{-2}(p>0.05)$ per decade in the net annual shortwave radiation gain by the lake (Fig. 8a). This was caused apparently by shortening the ice-covered period from $125 \mathrm{~d}$ (1979) to $72 \mathrm{~d}$ (2012) that reduced the lake surface albedo from the ice values (between 0.1 and 0.6) to the open-water albedo $(\sim 0.07)$, significantly increasing the amount of net annual solar radiation absorption by the lake. The net longwave radiation reduced at $-0.21 \mathrm{~W} \mathrm{~m}^{-2}$ per decade $(p>0.05$; Fig. $8 b)$. Concurrently, the downward longwave radiation increased at $3.22 \mathrm{~W} \mathrm{~m}^{-2}$ per decade $(p<0.01$; not shown). Hence, the decreasing trend of net longwave radiation was caused by the increased upward 
(a) Net shortwave radiation

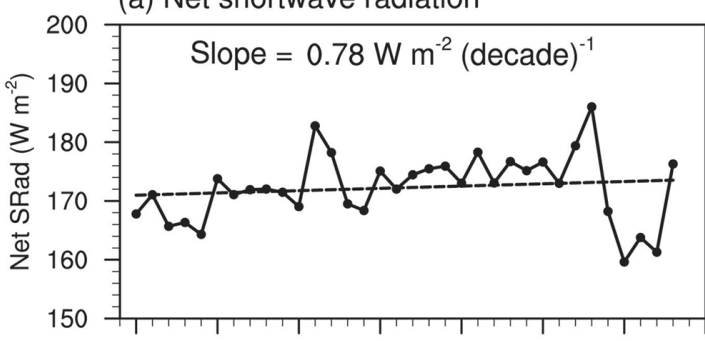

(c) Sensible heat flux

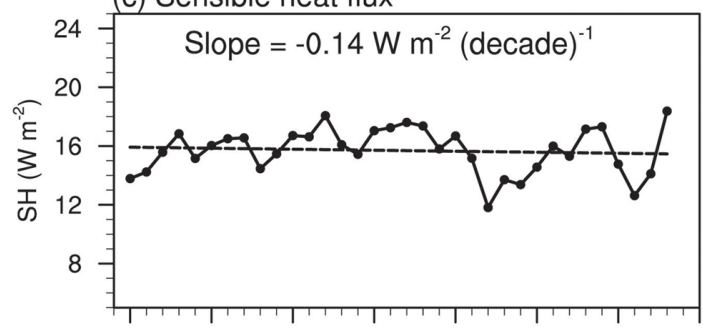

(e) Energy storage in water body

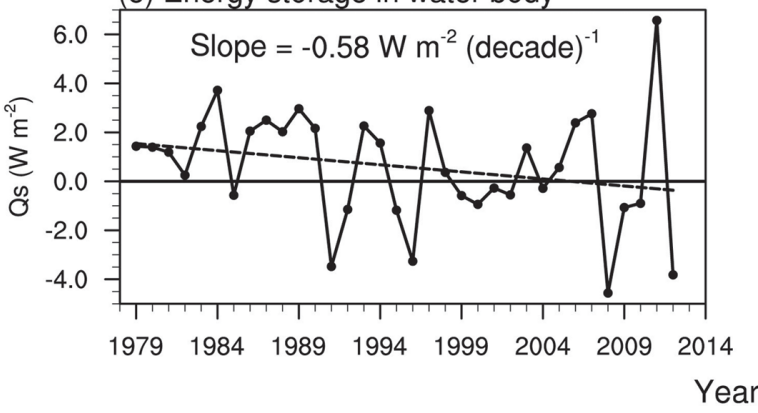

(b) Net longwave radiation

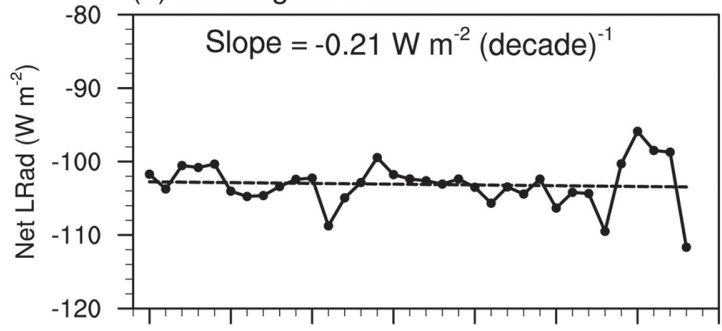

(d) Latent heat flux
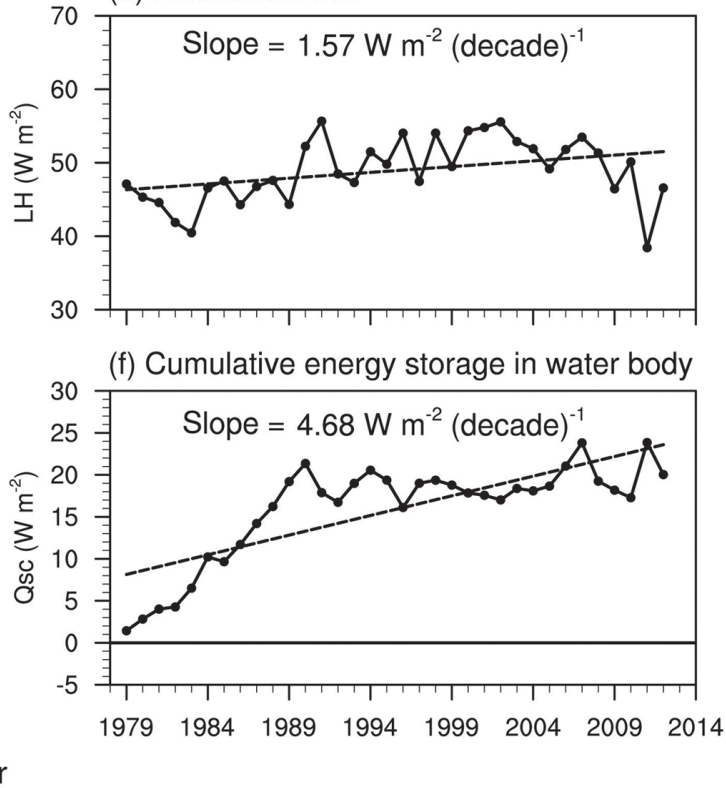

Figure 8. The interannual variation trend in simulated annual mean lake surface net shortwave radiation (a), net longwave radiation (b), sensible heat flux (c), latent heat flux (d), energy storage in water body (e) and cumulative energy storage in water body (f) from 1979 to 2012.

longwave radiation $\left(3.4 \mathrm{~W} \mathrm{~m}^{-2}\right.$ per decade, $\left.p<0.01\right)$ due to the rising LST during the open-water period and a shortening of the ice cover duration.

From 1979 to 2012, SH at Qinghai Lake decreased slightly at $-0.14 \mathrm{~W} \mathrm{~m}^{-2}$ per decade ( $p>0.05$; Fig. $\left.8 \mathrm{c}\right)$, while LH become stronger at $1.57 \mathrm{~W} \mathrm{~m}^{-2}$ per decade ( $p<0.05$; Fig. $\left.8 \mathrm{~d}\right)$. Hence, the additional heat gained due to the net radiation increase $\left(0.57 \mathrm{~W} \mathrm{~m}^{-2}\right.$ per decade, $\left.p>0.05\right)$ was mainly balanced by the increased $\mathrm{LH}$ due to evaporation. The average annual energy storage in the water body $\left(Q_{\mathrm{s}}\right.$, ice cover not included) of Qinghai Lake was close to equilibrium and showed a slight downward trend $\left(-0.58 \mathrm{~W} \mathrm{~m}^{-2}\right.$ per decade, $p>0.05$; Fig. 8e). The long-term interannual cumulative energy storage in turn showed an increasing trend $\left(4.68 \mathrm{~W} \mathrm{~m}^{-2}\right.$ per decade, $p<0.01$; Fig. $8 f$ ), which was consistent with the increasing lake mean water temperature.

\subsection{The lake-air temperature difference and the radiation flux}

The strong seasonal variation in the surface-air temperature differences is driven by the different thermal properties of the lake and the surrounding land surface (Haginoya et al., 2009; Desai et al., 2009). In the seasonal course averaged over the period 1979-2012, the 5d moving average air temperature was higher than LST during the ice-covered period (Fig. 9a), with the minimum lake-air temperature differences as low as $-6.9^{\circ} \mathrm{C}$ (Fig. 9b). After the ice-off between early April to mid-May, LST increased rapidly, particularly due to heating by the intense solar radiation (maximum $285.4 \mathrm{~W} \mathrm{~m}^{-2}$ for $5 \mathrm{~d}$ average), characteristic of high-altitude conditions on the TP (Fig. 9c), and exceeded the air temperature in June, reaching the maximum of $18.7^{\circ} \mathrm{C}$ in August (Fig. 9a). LST was generally higher than air temperature from June to January of the next year, which roughly coincided with the end of the openwater period. The mean lake-air temperature difference $(5 \mathrm{~d}$ moving average) became positive in June and kept increasing to a maximum of $12.8^{\circ} \mathrm{C}$ in December, just about 20 
$30 \mathrm{~d}$ before the ice cover formation (Fig. 9b). Owing to the large heat capacity of the lake, a clear phase lag existed between LST and air temperature. The time difference between the seasonal temperature maximums of the LST and the air temperature was about $20 \mathrm{~d}$, and the time difference between both values dropping to the freezing temperature of water of $0{ }^{\circ} \mathrm{C}$ was about 2 months.

From the perspective of interannual variability, both air temperature and LST had an increasing trend all year round, with stronger warming in winter than in summer (Fig. 9a). Although the downward longwave radiation increased in summer and autumn (average of $0.33 \mathrm{~W} \mathrm{~m}^{2} \mathrm{a}^{-1}$, maximum of $0.47 \mathrm{~W} \mathrm{~m}^{2} \mathrm{a}^{-1}$ in September; Fig. 9d), the LST increased slower than the air temperature, resulting in a reduction of lake-air temperature difference in autumn (average of $-0.04{ }^{\circ} \mathrm{Ca}^{-1}$, maximum of $-0.05^{\circ} \mathrm{Ca}^{-1}$ in November; Fig. 9b). This behaviour can be attributed to the apparent decrease in the downward shortwave radiation in summer (average of $-0.59 \mathrm{~W} \mathrm{~m}^{2} \mathrm{a}^{-1}$ ) and in autumn (average of $-0.11 \mathrm{~W} \mathrm{~m}^{2} \mathrm{a}^{-1}$ ), which reduced the net shortwave radiation absorption by the lake in summer and autumn (average of -0.55 and $-0.10 \mathrm{~W} \mathrm{~m}^{2} \mathrm{a}^{-1}$, respectively, Fig. 9c, e). In turn, the increased upward longwave radiation in summer and autumn (average of $\sim 0.22 \mathrm{~W} \mathrm{~m}^{2} \mathrm{a}^{-1}$; not shown) partially damped the effect of the downward longwave radiation increase (average of $0.33 \mathrm{~W} \mathrm{~m}^{2} \mathrm{a}^{-1}$ ), which lead to a decrease in the net longwave radiation from the lake to air (average of $\sim 0.19 \mathrm{~W} \mathrm{~m}^{2} \mathrm{a}^{-1}$ ) between mid-summer and late autumn (Fig. 9f).

In contrast to the inhibited positive trend of LST increase during the ice-free period, the monthly mean LST in early winter and late spring increased more rapidly than the air temperatures, with two apparent peaks of 0.24 and $0.12{ }^{\circ} \mathrm{Ca}^{-1}$ in January and May, respectively (Fig. 9a, b). The significant increase in LST in these periods may be related to the shift of the ice-on and break-up dates (grey areas in Fig. 9), as well as to the slight increase in solar radiation in December and April. The same seasonal pattern was reflected in the variations in the radiation balance (Fig. 9e, f): during the open-water period, the absorbed net shortwave radiation and released longwave net radiation at the lake surface had a generally consistent trend with downward shortwave radiation and downward longwave radiation, respectively, while during the ice formation period (the grey area around December-January in Fig. 9) and the thawing period (the grey area around April-May in Fig. 9), the absorbed net shortwave radiation and released longwave radiation had opposite trends to the downward shortwave radiation and downward longwave radiation, respectively. The net shortwave radiation increased obviously in these two periods (average of 0.57 and $0.53 \mathrm{~W} \mathrm{~m}^{2} \mathrm{a}^{-1}$, respectively), while the downward shortwave radiation was not (average of -0.05 and $-0.13 \mathrm{~W} \mathrm{~m}^{2} \mathrm{a}^{-1}$, respectively; Fig. 9c, e). The same is true for the net longwave radiation that decreased obviously in these two periods $\left(-0.31\right.$ and $-0.40 \mathrm{~W} \mathrm{~m}^{2} \mathrm{a}^{-1}$, respec- tively), although the downward longwave radiation had an increasing trend in each period $\left(0.34\right.$ and $\left.0.16 \mathrm{~W} \mathrm{~m}^{2} \mathrm{a}^{-1}\right)$ (Fig. 9d, f).

\subsection{Heat budget during ice-on and ice-off}

Since the dates of the lake ice break-up and freeze-up strongly affect the seasonal energy budget of the lake (Rouse et al., 2003; Jakkila et al., 2009), the heat budget and its longterm trends were considered in more detail. During the thawing period (the grey area around April-May in Fig. 10; same as in Fig. 9), the solar radiation was the strongest (average of $270.6 \mathrm{~W} \mathrm{~m}^{-2}$; Fig. 9c) on the background of appreciable downward longwave radiation (average of $246.1 \mathrm{~W} \mathrm{~m}^{-2}$; Fig. 9d). An earlier break-up date significantly reduced the albedo of the lake (from ice $\sim 0.6$ to water $\sim 0.07$ ), which led to an increase in the net shortwave radiation into the lake (Fig. 9e), which is same for the net radiation in April $\left(1.1 \mathrm{~W} \mathrm{~m}^{-2} \mathrm{a}^{-1}\right.$; Fig. 10c). Concurrently, the small lake-air temperature differences also ensured small SH and LH (average of -3.3 and $10.4 \mathrm{~W} \mathrm{~m}^{-2}$, respectively; Fig. 10a, b), which means that the heat release from the lake surface (the compound of net longwave radiation, $\mathrm{SH}$ and $\mathrm{LH}$ ) was low (Fig. 10d). As a consequence, the energy storage $\left(Q_{\mathrm{s}}\right)$ of the lake water body in this period (average of $\sim 91.7 \mathrm{~W} \mathrm{~m}^{-2}$ ) increased due to earlier ice break-up at $\sim 1.0 \mathrm{~W} \mathrm{~m}^{-2} \mathrm{a}^{-1}$ or at $\sim 1.1 \%$ per year (Fig. 10e).

In contrast, the freezing period (the grey area around December-January in Fig. 10) was characterized by the weakest levels of both downward shortwave and downward longwave radiation (average of $\sim 125.9$ and $\sim 166.5 \mathrm{~W} \mathrm{~m}^{-2}$, respectively; Fig. 9c, d). However, the upward longwave radiation (not shown) in this period was $\sim 1.7$ times larger than downward longwave radiation, causing a minimum of net radiation of $-45.3 \mathrm{~W} \mathrm{~m}^{-2}$ in December (Fig. 10c). Also, unlike in the thawing period, the values of upward $\mathrm{SH}$ and $\mathrm{LH}$ (average of 20.4 and $26.9 \mathrm{~W} \mathrm{~m}^{-2}$, respectively; Fig. 10a, b) both cannot be ignored because of a large lake-air temperature difference during this period. Hence, a later ice-on leads to an intense cooling of the lake water because the upward longwave radiation, $\mathrm{SH}$ and $\mathrm{LH}$ were not obstructed by the ice cover (Fig. 10a, b, c, d). The additional heat absorbed by the lake caused by earlier break-up in previous seasons released before freeze-up partly contributed to the delay of the freeze-up date of Qinghai Lake.

\section{Discussions and conclusions}

\subsection{Model performance}

The validation results indicate that FLake performed well for the extreme climatic conditions of the TP. Although there is an underestimation to the lake surface temperature in spring and an overestimation of it in rest of the seasons, it reproduced the observed seasonal variation in LST well and sim- 
(a) LST and air temperature

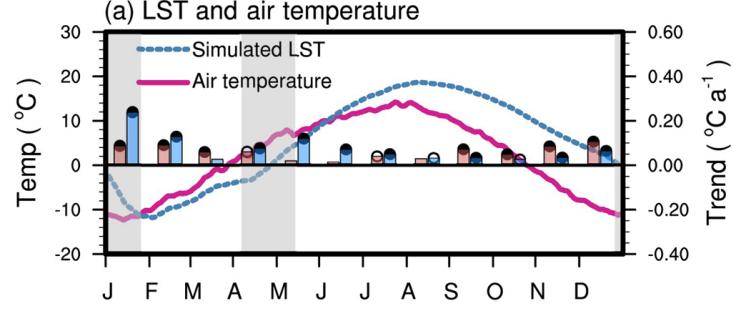

(c) Downward shortwave radiation

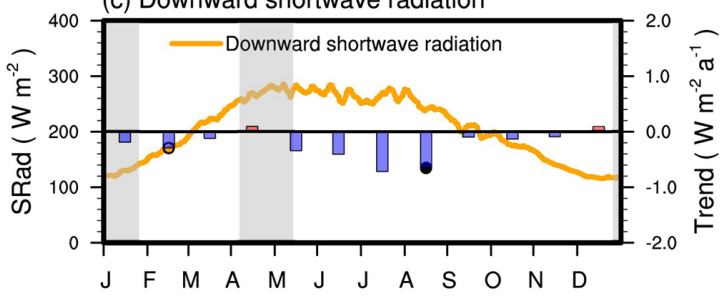

(e) Net shortwave radiation

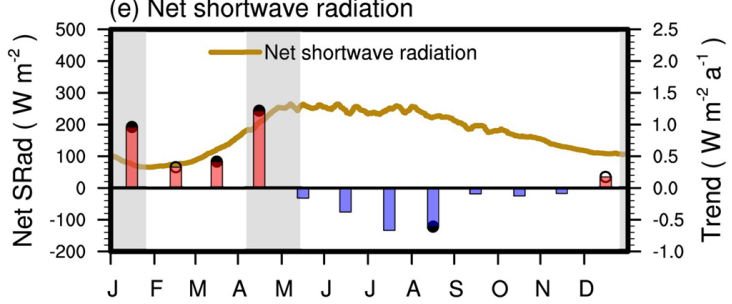

(b) Lake-air temperature difference

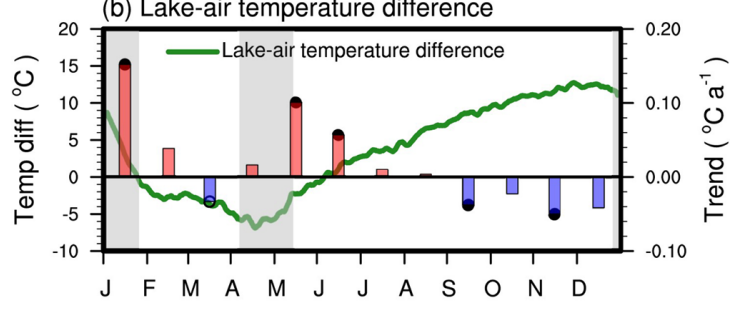

(d) Downward longwave radiation
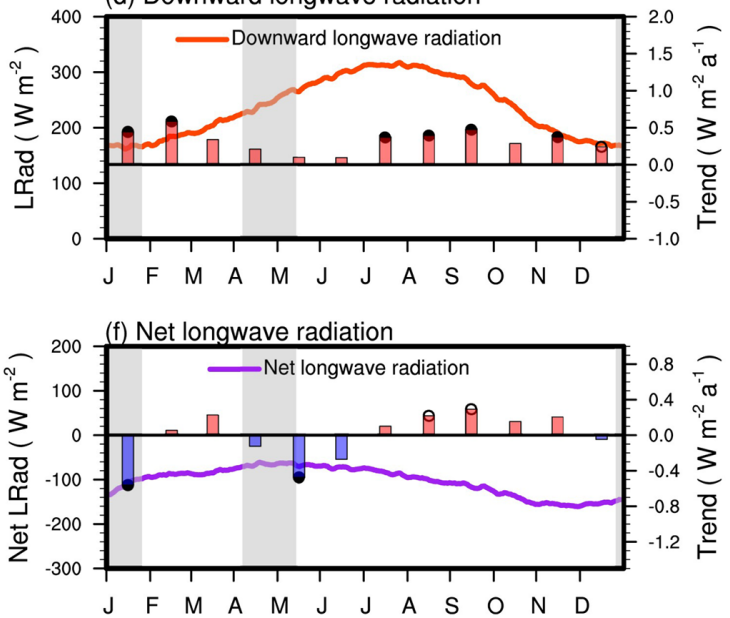

Figure 9. Climatological mean seasonal variations ( $5 \mathrm{~d}$ moving average, lines) in simulated LST and air temperature (a) with their difference (b), downward shortwave radiation (c), downward longwave radiation (d), net shortwave radiation (e) and net longwave radiation (f) at lake surface. The bars indicate their monthly averaged mean annual variation trend from 1979 to 2012, with red meaning positive trend and blue meaning negative trend, except in (a) for air temperature and LST, respectively. Solid points at end of the bars mean pass the significance test of $p<0.01$, and hollow points mean that $p<0.05$. The grey areas indicate the freeze-up and break-up date variation range of the lake.

ulated the thermal structure of the mixed layer and the thermocline reasonably. FLake can be considered a useful tool for studying the impact of the climate change to lakes on the TP.

The ITPCAS forcing data incorporating observations from land weather stations produced a constant bias when applied directly to model the lake surface conditions. The reason is the difference in the physical characteristics, in particular, air temperatures and wind speeds, between land and water, which is especially strong over the TP (Lazhu et al., 2016). The result is consistent with the findings of Kheyrollah Pour et al. (2012), who applied the FLake model to Great Slave Lake and Great Bear Lake in Canada. They also found that the model overestimated the LST when compared with the MODIS data because the forcing data were obtained at the land station rather than over the lake surface. In our case, the ITPCAS air temperatures are $0.71^{\circ} \mathrm{C}$ larger during daytime and $2.49^{\circ} \mathrm{C}$ smaller during nighttime compared to the buoy observations in summer and autumn. The ITPCAS wind speeds are $0.63 \mathrm{~m} \mathrm{~s}^{-1}$ lower during daytime and $1.83 \mathrm{~m} \mathrm{~s}^{-1}$ lower during nighttime. In turn, the daily variations in the air temperatures in ITPCAS data are almost 2.85 times higher than in the buoy observations. Lower wind speeds from ITPCAS forcing data weaken the heat transfer and lead to a warmer lake surface temperature simulated by FLake. Additionally, the wind speeds of ITPCAS data are smaller at night, corresponding with a higher simulated LST in the nighttime. This result proves that the deviation of the ITPCAS forcing data indeed leads to a warmer simulated LST. Hence, the choice of atmospheric forcing is crucial for the simulation of large lakes in the extreme highland conditions of the TP. In the absence of long-term weather observations over the lake surface, a correction procedure can be applied to the forcing data based on the available shortterm observations from moored stations (buoys) and/or satellite information. In this study, a comparison with short-term observation data from the buoy on lake surface allowed correction of the ITPCAS forcing data, significantly reducing the bias between the model and the remote sensing data.

The simulated seasonal stratification regime suggests that Qinghai Lake is dimictic, with the spring overturn taking place around May and the autumn overturn appearing around November-December. Currently, there is no long-term information available on the vertical thermal structure of Qinghai Lake. The stratification pattern simulated in this study is, however, very similar to the observations from another Tibetan lake, Bangong Co (Wang et al., 2014). Salinity can influence the temperature of maximum density $\left(T_{\mathrm{m}}\right)$ and 

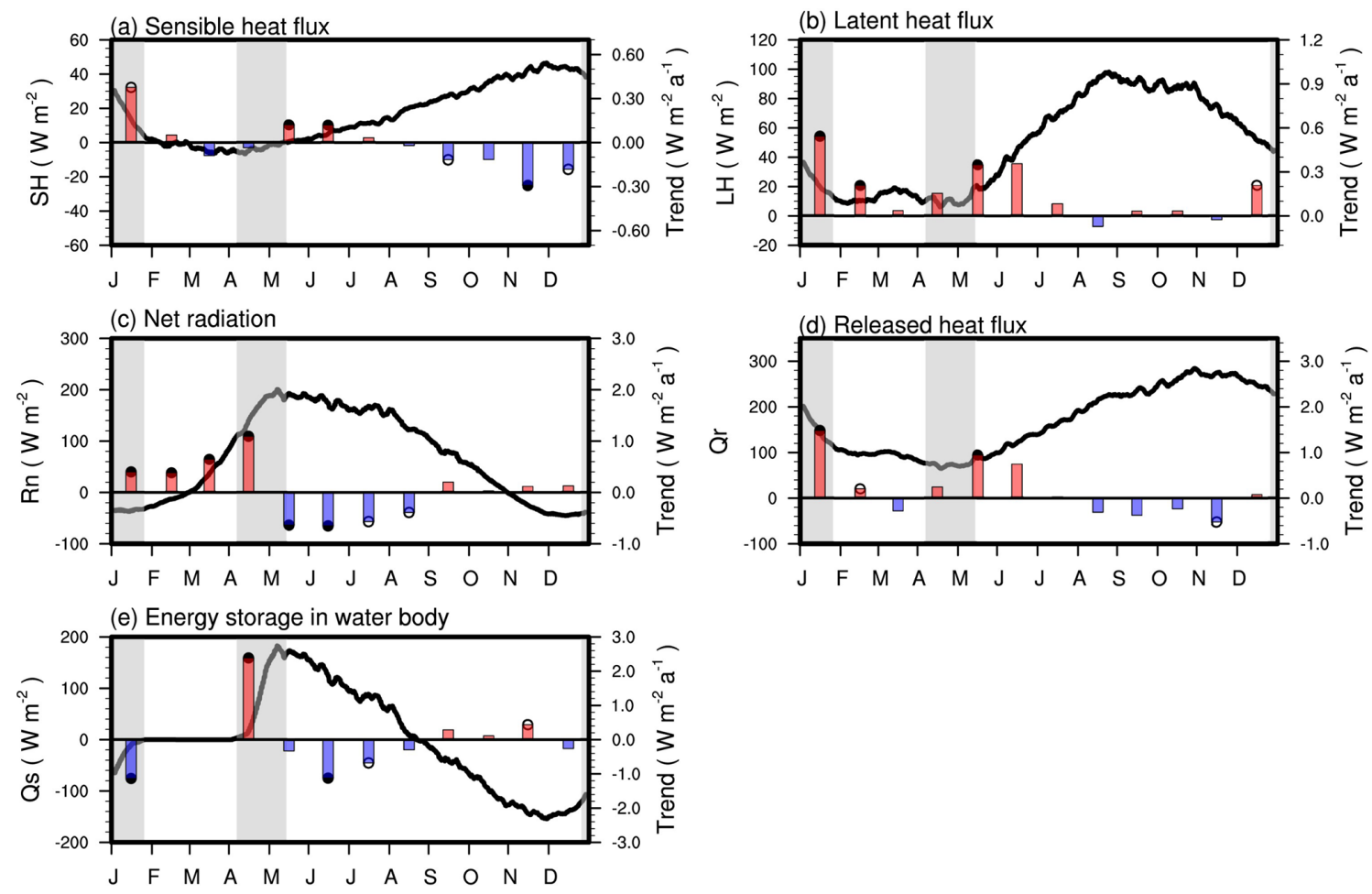

Figure 10. Climatological mean seasonal variations ( $5 \mathrm{~d}$ moving average, lines) in the simulated sensible heat flux (a), latent heat flux (b), net radiation (c), released heat flux at lake surface (d) and energy storage in water body (e). The bars indicate their monthly averaged mean annual variation trend from 1979-2012, with red meaning positive trend and blue meaning negative trend. Solid points at end of the bars mean a pass of the significance test of $p<0.01$, and hollow points mean that $p<0.05$. The grey areas indicate the freeze-up and break-up date variation range of the lake.

the freezing temperature of water $\left(T_{\mathrm{f}}\right)$. According to the $12.5 \mathrm{~g} \mathrm{~L}^{-1}$ salinity of Qinghai Lake, these two parameters equal 1.28 and $-0.69^{\circ} \mathrm{C}$ instead of the default model configurations of 4 and $0^{\circ} \mathrm{C}$, respectively. Considerations of the salinity effects lead to a slightly earlier spring overturn and a later autumn overturn, and consequently to an extension of the lake stratification period. Because the salinity stratification effects cannot be completely included in the model designed for freshwater lakes, the simulated mixing regime may have some differences from the actual situation of Qinghai Lake.

Despite incorporation of the salinity effects on $T_{\mathrm{m}}$ and $T_{\mathrm{f}}$ improved simulation accuracy of maximum ice thickness and break-up date, the ice phenology modelled by FLake still differs from the remote sensing observations. The discrepancy may be related to a number of factors not included in the model. One of them is the effect of salinity on the ice structure, density and porosity; the others are precipitation, inflows, circulation under ice cover and wind, which are especially important for large-area lakes (Kirillin et al., 2012; Kouraev et al., 2007) such as Qinghai Lake. However, the air temperature apparently has the strongest effect on ice regime, especially in long-term changes, which appear to be simu- lated well by FLake, allowing us to study the effect of climate change on lake ice regime within the model ability.

Following the studies of Lazhu et al. (2016) on Nam Co Lake (salinity $\sim 1.78 \mathrm{~g} \mathrm{~L}^{-1}$ ) and Kirillin et al. (2017) on freshwater lakes Ngoring and Gyaring, the good prediction of the LST over the largest, brackish lake of the TP by the relatively simple, highly parameterized model FLake, verified by satellite and buoy data, is one of the core results of this study. Both the importance of the TP for global climate interactions and the lack of continuous observations in this region demand reliable modelling schemes to take into account the complexity of the land-atmosphere interactions. FLake is currently among the few lake parameterization schemes actively used in regional climate models and numerical weather prediction (NWP). Complementary to the recent study of Kirillin et al. (2017), who successfully applied FLake to the freshwater lakes of the TP, the present study demonstrates that the model adequately simulates the major mechanisms of the air-lake interaction in large brackish lakes of the TP. Hence, FLake can significantly improve the simulation of the land-atmosphere interaction in regional climate models and NWP, which is crucial for understanding the climate-driven changes in this key region. To a first approximation, the result suggests the applicability of FLake to the simulation of 
all large brackish waters. The latter are characteristic features of arid regions worldwide, having a strong impact on regional climate and the water budget.

We have found that the duration of the ice-covered period is crucial for the lake-atmosphere interaction on the TP, with periods of ice-on and ice-off having the strongest effect both on the radiation balance and the boundary heat exchange by SH and LH. To simulate the ice cover duration properly, the heat storage in winter and the vertical heat transport across the ice-covered water column should be adequately described. In its present version, FLake treats these in a simplistic way, neglecting the heating of water column by solar radiation penetrating the ice cover (Kirillin et al., 2017). This simplification is a source of potential errors in the simulated ice break-up date and LST after the break-up, which errors can be significant for the Tibetan conditions, taking into account the strong solar radiation and low snow precipitation on the TP in winter. In earlier studies on lowland lakes, FLake tended to predict earlier break-up dates because of the absence of snow in the FLake model (Bernhardt et al., 2012; Kheyrollah Pour et al., 2012). In this study, the simulated break-up date is generally later than observation, which can be treated as an indication of the importance of the underice water column heating by solar radiation neglected in the model. Another factor potentially introducing the uncertainty into the simulation of the ice duration is the ice albedo. The latter was recently estimated in Qinghai Lake to be much lower than typical estimates for lakes: ice albedo obtained by MODIS was less than 0.25 under the snow-free condition and less than 0.4, even under the snow cover condition ( $\mathrm{Li}$ et al., 2018; Lang et al., 2018). Among the reasons for such a low ice albedo that may be mentioned are the effects of salt on the ice structure and deformation of the ice surface under the influence of the strong solar radiation. As a result, standard modelling approaches may underestimate the amount of shortwave radiation penetrating the ice, with subsequent errors predicting the ice duration and underestimation of the LST after ice break-up.

The LST acquired by the MODIS, which is used as a reference for validation of simulation results, is generally lower than the in situ LST. This discrepancy may partly be contributed by the cool skin effect (Crosman and Horel, 2009), which is also found to be stronger in high-altitude lakes than in the ocean due to strong solar radiative heating and cooler air temperature at lake surface ( $\mathrm{Li}$ et al., 2015; Wen et al., 2016). This suggests that the model predictions of the bulk LST may be better than what the comparison against the satellite data shows, though exact estimation and correction of the cool skin effect is out of the scope of this study.

\subsection{Response of Qinghai Lake to climate change}

As expected, the correlation analysis shows that the changes in LST are closely related to air temperatures, downward longwave radiation and wind speed (Fig. 6). The increase in the air temperature and downward longwave radiation plays a key role in lake surface temperature warming, and the decrease in wind speed also promoted the warming of the lake surface temperature. The downward shortwave radiation is negatively and insignificantly $(R<0.3)$ correlated with the water temperature, which can also explain the slower increase in the water temperature compared with the air temperature (see Kirillin et al., 2017). The decrease in ice cover duration increases, in turn, the annual amount of shortwave radiation penetrating the water column, accelerating the net warming. Annual mean LST simulated by FLake increased at a rate of $0.74{ }^{\circ} \mathrm{C}$ per decade, primarily due to rising air temperature and decreasing wind speed. The warming trend of simulated LST significantly exceeded that of the regional air temperature $\left(0.58^{\circ} \mathrm{C}\right.$ per decade $)$. This discrepancy may be caused by declining winter ice cover, which leads to an earlier start of the stratified season that significantly increases the LST (Austin and Colman, 2007). Mixed-layer and water mean column temperature increased by 0.38 and $0.26^{\circ} \mathrm{C}$ from 1979 to 2012, respectively, while the bottom temperature increased slowly from 1979 to 1989 and has even a slight decreasing trend from 1989 to 2012 . The slight decrease in the deep temperatures agrees with findings of Kirillin et al. (2017) from freshwater Ngoring Lake on the TP and the research of Huang et al. (2017) that uses the General Lake Model (GLM) at another TP lake, Nam Co. The apparent reason for the deep cooling is the increase in stability of the lake due to surface warming, which restricts heat transfer from surface to bottom and produces a decrease in the bottom water temperature. This behaviour has been reported as a characteristic in previous studies on lowland dimictic lakes (Hondzo and Stefan, 1993; Danis et al., 2004; Kirillin, 2010).

As mentioned above, climate change is found to have a strong impact on lake ice phenology. The maximum ice thickness of Qinghai Lake decreases in simulations, and significant tendencies to later ice-on and earlier ice-off are predicted. These three ice phenology characteristics are correlated with the January-April, November-December and March-April air temperature, respectively. The ability to accurately represent ice cover on lakes is essential for the improvement of global circulation models, regional climate models and numerical weather forecasting (Brown and Duguay, 2010). We have shown that the net shortwave radiation increase caused by a shortening of the ice duration plays a key role in net radiation increase. Hence, the declining winter ice cover has a significant influence on the annual radiation balance of the lake.

In total, the annual energy storage in water body of Qinghai Lake $\left(Q_{\mathrm{s}}\right)$ decreased at a slow rate of $-0.58 \mathrm{~W} \mathrm{~m}^{-2}$ per decade, influenced primarily by the increase in received net radiation and released $\mathrm{LH}$ at the lake surface (Fig. 8e). Still, the cumulative energy storage of the lake is increasing at $4.68 \mathrm{~W} \mathrm{~m}^{-2}$ per decade ( $p>0.01$; Fig. $\left.8 \mathrm{f}\right)$, consistent with the trend of the mean water column temperature. Change of freeze-up or break-up date dramatically influenced the lake 
energy and heat budget during the ice formation or decay period. The earlier thaw of ice causes an increase in energy absorbed by the lake in late spring, since more solar radiation comes into the lake without reflection by the ice cover. The delayed freeze-up date leads to an increase in energy lost before freeze-up due to strong upward longwave radiation, $\mathrm{SH}$ and $\mathrm{LH}$.

\subsection{Differences between the highland TP lakes and lakes of other regions}

For low-altitude temperate and boreal lakes, the air temperatures are typically higher than LST after the ice-off and remain higher until temperature equilibrates around midsummer. In the subsequent period down to ice-on, the LSTs are typically higher than the air temperatures. Hence, the atmospheric boundary layer is generally stable throughout much of the summer season over low-altitude lakes (Scott and Huff, 1996; Rouse et al., 2003; Gianniou and Antonopoulos, 2007; Momii and Ito, 2008; Nordbo et al., 2011). Due to a higher altitude, the lakes on the TP have a lower atmospheric thickness and air density, and the solar radiation over the plateau is much stronger than in other areas of the same latitude, while the air temperatures are comparably low (Wen et al., 2016; Haginoya et al., 2009; Li et al., 2016). These specific climatic conditions cause a significantly different seasonal interaction between the lake and the atmosphere. In this study, the LST of Qinghai Lake increased very fast after ice melt in mid-April under the strong solar radiation and equilibrated with air temperature in June, which is much earlier than in low-altitude lakes. The difference between air temperature and LST is the fundamental property of lake-air interaction, determining the intensity of the surface heat exchange by means of atmospheric stability. When the LST is higher than air temperature, which is the case for the TP lakes in summer, the atmosphere over the lake becomes increasingly unstable, accelerating the release of heat to the atmosphere by convection. In that sense, the role of lakes, as hotspots of the land-atmosphere interaction on the $\mathrm{TP}$, consists of the accumulation of the solar radiation and release of the accumulated heat into the air by the convective exchange. This fact also determines the differences in the response of TP lakes to regional climate change compared to that found previously in low-altitude areas.

Data availability. The ITPCAS dataset is publicly available at http://en.tpedatabase.cn (ITPCAS, 2019). The dataset of lake ice phenology in Qinghai Lake from 2000 to 2018 is publicly available through the Science Data Bank (https://doi.org/10.11922/sciencedb.634; Qi et al., 2018). The lake model FLake is freely available at http://www.lakemodel.net (FLake Core Team, 2019). The model configuration files and the output of the lake model are available from the first author by request.
Author contributions. DS and LW conceived the study. XH provided the buoy data. DS performed the modelling with contributions from LW and GK. LZ, ZL and JD performed analysis of remote sensing data. DS, LW, SL, XG and GK analysed the model output. DS wrote the paper, with contributions from all co-authors.

Competing interests. The authors declare that they have no conflict of interest.

Special issue statement. This article is part of the special issue "Modelling lakes in the climate system (GMD/HESS inter-journal SI)". It is a result of the 5th workshop on "Parameterization of Lakes in Numerical Weather Prediction and Climate Modelling", Berlin, Germany, 16-19 October 2017.

Acknowledgements. The study was supported by the National Natural Science Foundation of China (NSFC, 91637107); the bilateral research project GZ1259 supported by the Sino-German Center for Research Support; the CAS "Light of West China" project Y929641001; and NSFC 41775016, 41605011 and 41811530387. Georgiy Kirillin was supported by the German Science Foundation (DFG Projects KI-853-11/2 and KI-853-13/1). The authors are grateful to Matti Leppäranta for advice and comments on the paper.

Review statement. This paper was edited by Miguel Potes and reviewed by two anonymous referees.

\section{References}

Adrian, R., O’Reilly, C. M., Zagarese, H., Baines S. B., Hessen, D. O., Keller, W., Livingstone, D. M., Sommaruga, R., Straile, D., Van, D. E., Weyhenmeyer, G. A., and Winder, M.: Lakes as sentinels of climate change, J. Limnol. Oceanogr., 54, 2283-2297, https://doi.org/10.4319/lo.2009.54.6_part_2.2283, 2009.

Austin, J. A. and Colman, S. M.: Lake Superior summer water temperatures are increasing more rapidly than regional air temperatures: A positive ice-albedo feedback, J. Geophys. Res. Lett., 34, L06604, https://doi.org/10.1029/2006GL029021, 2007.

Bernhardt, J., Engelhardt, C., Kirillin, G., and Matschullat, J.: Lake ice phenology in Berlin-Brandenburg from 1947-2007: observations and model hindcasts, Climatic Change, 112, 791-817, 2012.

Boehrer, B. and Schultze, M.: Stratification of lakes, Rev. Geophys., 46, RG2005, https://doi.org/10.1029/2006RG000210, 2008.

Bonan, G. B.: Sensitivity of a GCM Simulation to Inclusion of Inland Water Surfaces, J. Climate, 8, 2691-2704, https://doi.org/10.1175/15200442(1995)008<2691:SOAGST>2.0.CO;2, 1995.

Brown, L. C. and Duguay, C. R.: The response and role of ice cover in lake-climate interactions, Prog. Phys. Geog., 34, 671704, https://doi.org/10.1177/0309133310375653, 2010. 
Caldwell, D. R.: The maximum density points of pure and saline water, Deep Sea Res., 25, 175-181, https://doi.org/10.1016/0146-6291(78)90005-x, 1978.

Chen, X., Wang, G., Li, W., Zeng, Q., Jin, D., and Wang, L.: Lake Ice and Its Remote Sensing Monitoring in the Tibetan Plateau, Journal of Glaciology and Geocryology, 17, 241-246, 1995 (in Chinese).

Chen, Y., Yang, K., He, J., Qin, J., Shi, J., Du, J., and He, Q.: Improving land surface temperature modeling for dry land of China, J. Geophys. Res., 116, D20104, https://doi.org/10.1029/2011JD015921, 2011.

Crawford, T. M. and Duchon, C. E.: An improved parameterization for estimating effective atmospheric emissivity for use in calculating daytime downwelling longwave radiation, J. Appl. Meteorol., 38, 474-480, https://doi.org/10.1175/15200450(1999)038<0474:AIPFEE>2.0.CO;2, 1999.

Crosman, E. T. and Horel, J. D.: MODIS-derived surface temperature of the Great Salt Lake, Remote Sens. Environ., 113, 73-81, https://doi.org/10.1016/j.rse.2008.08.013, 2009.

Cui, B. L. and Li, X. Y.: The impact of climate changes on water level of Qinghai Lake in China over the past 50 years, Hydrol. Res., 47, 532-542, https://doi.org/10.2166/nh.2015.237, 2016.

Danis, P. A., Grafenstein, U. V., Masson-Delmotte, V., Planton, S., Gerdeaux, D., and Moisselin, J. M.: Vulnerability of two European lakes in response to future climatic changes, Geophys. Res. Lett., 31, L21507, https://doi.org/10.1029/2004GL020833, 2004.

Deng, S., Dong, H., Lv, G., Jiang, H., Yu, B., and Bishop, M. E.: Microbial dolomite precipitation using sulfate reducing and halophilic bacteria: Results from Qinghai Lake, Tibetan Plateau, NW China, Chem. Geol., 278, 151-159, https://doi.org/10.1016/j.chemgeo.2010.09.008, 2010.

Desai, A. R., Austin, J. A., Bennington, V., and McKinley, G. A.: Stronger winds over a large lake in response to weakening air-to-lake temperature gradient, Nat. Geosci., 2, 855-858, https://doi.org/10.1038/ngeo693, 2009.

Ding, Z., Lu, R., Liu, C., and Duan, C.: Temporal change characteristics of climatic and its relationships with atmospheric circulation patterns in Qinghai Lake Basin, Advances in Earth Science, 33, 281-292, https://doi.org/10.11867/j.issn.10018166.2018.03.0281, 2018 (in Chinese).

Dong, H. and Song, Y.: Shrinkage history of Lake Qinghai and causes during the last 52 years, 2011 International Symposium on Water Resource and Environmental Protection (ISWREP), Xi'an, China, 20-22 May 2011, 446-449, 2011.

Donlon, C. J., Minnett, P. J., Gentemann, C., Nightingale, T. J., Barton, I. J., Ward, B., and Murray, M. J.: Toward Improved Validation of Satellite Sea Surface Skin Temperature Measurements for Climate Research, J. Climate, 15, 353-369, https://doi.org/10.1175/15200442(2002)015<0353:TIVOSS>2.0.CO;2, 2002.

Duan, A. and Xiao, Z.: Does the climate warming hiatus exist over the Tibetan Plateau?, Sci. Rep.-UK, 5, 13711, https://doi.org/10.1038/srep13711, 2015.

Duan, A. M. and Wu, G. X.: Role of the Tibetan Plateau thermal forcing in the summer climate patterns over subtropical Asia, Clim. Dynam., 24, 793-807, https://doi.org/10.1007/s00382004-0488-8, 2005.

Duguay, C. R., Prowse, T. D., Bonsal, B. R., Brown, R. D., Lacroix, M. P., and Ménard, P.: Recent trends in
Canadian lake ice cover, Hydrol. Process., 20, 781-801, https://doi.org/10.1002/hyp.6131, 2006.

Dutra, E., Stepanenko, V. M., Balsamo, G., Viterbo, P., Miranda, P. M. A., Mironov, D., and Schär, C.: An offline study of the impact of lakes on the performance of the ECMWF surface scheme, Boreal Environ. Res., 15, 100-112, 2010.

Eerola, K., Rontu, L., Kourzeneva, E., and Shcherbak, E.: A study on effects of lake temperature and ice cover in HIRLAM, Boreal. Environ. Res., 15, 130-142, 2010.

FLake Core Team: The FLake (Fluxes in Lakes) model, available at: http://www.lakemodel.net, last access: 15 April 2019.

Gao, Y., Tang, M., Luo, S., Shen, Z., and Li, C.: Some aspects of recent research on the Qinghai-Xizang Plateau meteorology, B. Am. Meteorol. Soc., 62, 31-35, https://doi.org/10.1175/15200477(1981)062<0031:SAORRO>2.0.CO;2, 1981.

Guo, D. and Wang, H.: The significant climate warming in the northern Tibetan Plateau and its possible causes, Int. J. Climatol., 32, 1775-1781, https://doi.org/10.1002/joc.2388, 2012.

Guo, D. and Wang, H.: Simulation of permafrost and seasonally frozen ground conditions on the Tibetan Plateau, 1981-2010, J. Geophys. Res.-Atmos., 118, 5216-5230, https://doi.org/10.1002/jgrd.50457, 2013.

Gianniou, S. K. and Antonopoulos, V. Z.: Evaporation and energy budget in Lake Vegoritis, Greece, J. Hydrol., 345, 212-223, https://doi.org/10.1016/j.jhydrol.2007.08.007, 2007.

Haginoya, S., Fujii, H., Kuwagata, T., Xu, J., Ishigooka, Y., Kang, S., and Zhang, Y.: Air-lake interaction features found in heat and water exchanges over Nam Co on the Tibetan Plateau, Sola, 5, 172-175, https://doi.org/10.2151/sola.2009-044, 2009.

Hondzo, M. and Stefan, H. G.: Regional water temperature characteristics of lakes subjected to climate change, Climatic Change, 24, 187-211, https://doi.org/10.1007/BF01091829, 1993.

Huang, L., Wang, J., Zhu, L., Ju, J., and Daut, G.: The warming of large lakes on the Tibetan Plateau: Evidence from a lake model simulation of Nam Co, China, during 1979-2012, J. Geophys. Res.-Atmos., 122, 13095-13107, https://doi.org/10.1002/2017JD027379, 2017.

ITPCAS: Third Pole Environment Database, available at: http://en. tpedatabase.cn, last access: 15 April 2019.

Jakkila, J., Leppäranta, M., Kawamura, T., Shirasawa, K., and Salonen, K.: Radiation transfer and heat budget during the ice season in Lake Pääjärvi, Finland, Aquat. Ecol., 43, 681-692, https://doi.org/10.1007/s10452-009-9275-2, 2009.

Kirillin, G.: Modeling the impact of global warming on water temperature and seasonal mixing regimes in small temperate lakes, Boreal Environ. Res., 15, 279-293, 2010.

Kirillin, G. and Shatwell, T.: Generalized scaling of seasonal thermal stratification in lakes, Earth-Sci. Rev., 161, 179-190, https://doi.org/10.1016/j.earscirev.2016.08.008, 2016.

Kirillin, G., Leppäranta, M., Terzhevik, A., Granin, N., Bernhardt, J., Engelhardt, C., Efremova, T., Golosov, S., Palshin, N., Sherstyankin, P., Zdorovennova, G., and Zdorovennov, R.: Physics of seasonally ice-covered lakes: a review, Aquat. Sci., 74, 659-682, 2012.

Kirillin, G., Wen, L., and Shatwell, T.: Seasonal thermal regime and climatic trends in lakes of the Tibetan highlands, Hydrol. Earth Syst. Sci., 21, 1895-1909, https://doi.org/10.5194/hess-21-18952017, 2017. 
Kheyrollah Pour, H., Duguay, C. R., Martynov, A., and Brown, L. C.: Simulation of surface temperature and ice cover of large northern lakes with 1-D models: a comparison with MODIS satellite data and in situ measurements, Tellus A, 64, 17614, https://doi.org/10.3402/tellusa.v64i0.17614, 2012.

Kitaigorodskii, S. A. and Miropolsky, Y. Z.: On theory of open ocean active layer, Izvestiya Akademii Nauk SSSR Fizika Atmosfery I Okeana, 6, 177-188, 1970.

Kouraev, A., V., Semovski, S., V., Shimaraev, M., N., Mognard, N., M., Legrésy, B., and Rémy, F.: The ice regime of Lake Baikal from historical and satellite data: Relationship to air temperature, dynamical, and other factors, Limnol. Oceanogr., 52, 1268-1286, https://doi.org/10.4319/lo.2007.52.3.1268, 2007.

Lang, J., Lyu, S., Li, Z., Ma, Y., and Su, D.: An Investigation of Ice Surface Albedo and Its Influence on the HighAltitude Lakes of the Tibetan Plateau, Remote Sensing, 10, 218, https://doi.org/10.3390/rs10020218, 2018.

Langer, M., Westermann, S., and Boike, J.: Spatial and temporal variations of summer surface temperatures of wet polygonal tundra in Siberia-implications for MODIS LST based permafrost monitoring, Remote Sens. Environ., 114, 2059-2069, https://doi.org/10.1016/j.rse.2010.04.012, 2010.

Latifovic, R. and Pouliot, D.: Analysis of climate change impacts on lake ice phenology in Canada using the historical satellite data record, Remote. Sens. Environ., 106, 492-507, https://doi.org/10.1016/j.rse.2006.09.015, 2007.

Lazhu, Yang, K., Wang, J., Lei, Y., Chen, Y., Zhu, L., Ding, B., and Qin, J.: Quantifying evaporation and its decadal change for Lake Nam Co, central Tibetan Plateau, J. Geophys. Res.-Atmos., 121, 7578-7591, https://doi.org/10.1002/2015JD024523, 2016.

Lei, Y., Yang, K., Wang, B., Shen, Y., Bird, B. W., Zhang, G., and Tian, L.: Response of inland lake dynamics over the Tibetan Plateau to climate change, Climatic Change, 125, 281-290, https://doi.org/10.1007/s10584-014-1175-3, 2014.

Leppäranta, M. and Lewis, J. E.: Observations of ice surface temperature and thickness in the Baltic Sea, Int. J. Remote Sens., 28, 3963-3977, https://doi.org/10.1080/01431160601075616, 2007.

Li, X. Y., Xu, H. Y., Sun, Y. L., Zhang, D. S., and Yang, Z. P.: LakeLevel Change and Water Balance Analysis at Lake Qinghai, West China during Recent Decades, Water Resour. Manag., 21, 15051516, https://doi.org/10.1007/s11269-006-9096-1, 2007.

Li, X. Y., Ma, Y. J., Huang, Y. M., Hu, X., Wu, X. C., Wang, P., Li, G. Y., Zhang, S. Y., Wu, H. W., Jiang, Z. Y., Cui, B. L., and Liu, L.: Evaporation and surface energy budget over the largest high-altitude saline lake on the QinghaiTibet Plateau, J. Geophys. Res.-Atmos., 121, 10470-10485, https://doi.org/10.1002/2016JD025027, 2016.

Li, Z., Lyu, S., Ao, Y., Wen, L., Zhao, L., and Wang, S.: Long-term energy flux and radiation balance observations over Lake Ngoring, Tibetan Plateau, Atmos. Res., 155, 13-25, https://doi.org/10.1016/j.atmosres.2014.11.019, 2015.

Li, Z., Ao, Y., Lyu, S., and Lang, J.: Investigation of the ice surface albedo in the Tibetan Plateau lakes based on the field observation and MODIS products, J. Glaciol., 64, 506-516, https://doi.org/10.1017/jog.2018.35, 2018.

Liao, J., Shen, G., and Li, Y.: Lake variations in response to climate change in the Tibetan Plateau in the past 40 years, Int. J. Digit. Earth, 6, 534-549, https://doi.org/10.1080/17538947.2012.656290, 2013.
Liu, J.-G. and Xie, Z.-H.: Improving simulation of soil moisture in China using a multiple meteorological forcing ensemble approach, Hydrol. Earth Syst. Sci., 17, 3355-3369, https://doi.org/10.5194/hess-17-3355-2013, 2013.

Livingstone, D. M.: Impact of secular climate change on the thermal structure of a large temperate central European lake, Climatic Change, 57, 205-225, https://doi.org/10.1023/A:1022119503144, 2003.

Livingstone, D. M.: A Change of Climate Provokes a Change of Paradigm: Taking Leave of Two Tacit Assumptions about Physical Lake Forcing, Int. Rev. Hydrobiol., 93, 404-414, https://doi.org/10.1002/iroh.200811061, 2008.

Ma, R. H., Yang, G. S., Duan, H. T., Jiang, J. H., Wang, S. M., Feng, X. Z., Li, A. N., Kong, F. X., Xue, B., Wu, J. L., and Li, S. J.: China's lakes at present: number, area and spatial distribution, Sci. China Earth Sci., 54, 283-289, https://doi.org/10.1007/s11430-010-4052-6, 2011.

Ma, Y., Wang, Y., Wu, R., Hu, Z., Yang, K., Li, M., Ma, W., Zhong, L., Sun, F., Chen, X., Zhu, Z., Wang, S., and Ishikawa, H.: Recent advances on the study of atmosphere-land interaction observations on the Tibetan Plateau, Hydrol. Earth Syst. Sci., 13, 1103-1111, https://doi.org/10.5194/hess-13-1103-2009, 2009.

Magnuson, J. J., Robertson, D. M., Benson, B. J., Wynne, R. H., Livingstone, D. M., Arai, T., Assel, R. A., Barry, R. G., Card, V., Kuusisto, E., Granin, N. G., Prowse, T. D., Stewart, K. M., and Vuglinski, V. S.: Historical trends in lake and river ice cover in the Northern Hemisphere, Science, 289, 1743-1746, https://doi.org/10.1126/science.289.5485.1743, 2000.

Mallard, M. S., Nolte, C. G., Bullock, O. R., Spero, T. L., and Gula, J.: Using a coupled lake model with WRF for dynamical downscaling, J. Geophys. Res.-Atmos., 119, 7193-7208, https://doi.org/10.1002/2014JD021785, 2014.

Minnett, P. J.: Radiometric measurements of the sea-surface skin temperature: The competing roles of the diurnal thermocline and the cool skin, Int. J. Remote. Sens., 24, 5033-5047, https://doi.org/10.1080/0143116031000095880, 2003.

Mironov, D. V.: Parameterization of lakes in numerical weather prediction. Description of a lake model. COSMO Technical Report, Deutscher Wetterdienst, Offenbach am Main, Germany, 2008.

Momii, K. and Ito, Y.: Heat budget estimates for lake Ikeda, Japan, J. Hydrol., 361, 362-370, https://doi.org/10.1016/j.jhydrol.2008.08.004, 2008.

Nordbo, A., Launiainen, S., Mammarella, I., Leppäranta, M., Huotari, J., Ojala, A., and Vesala, T.: Long-term energy flux measurements and energy balance over a small boreal lake using eddy covariance technique, J. Geophys. Res., 116, D02119, https://doi.org/10.1029/2010JD014542, 2011.

O'Reilly, C. M., Sharma, S., Gray, D. K., Hampton, S. E., Read, J. S., Rowley, R. J., Schneider, P., Lenters, J. D., McIntyre, P. B., Kraemer, B. M., Weyhenmeyer, G. A., Straile, D., Dong, B., Adrian, R., Allan, M. G., Anneville, O., Arvola, L., Austin, J., Bailey, J. L., Baron, J. S., Brookes, J. D., Eyto, E., Dokulil, M. T., Hamilton, D. P., Havens, K., Hetherington, A. L., Higgins, S. N., Hook, S., Izmest'eva, L. R., Joehnk, K. D., Kangur, K., Kasprzak, P., Kumagai, M., Kuusisto, E., Leshkevich, G., Livingstone, D. M., MacIntyre, S., May, L., Melack, J. M., MuellerNavarra, D. C., Naumenko, M., Noges, P., Noges, T., North, R. P., Plisnier, P.-D., Rigosi, A., Rimmer, A., Rogora, M., Rudstam, L. G., Rusak, J. A., Salmaso, N., Samal, N. R., Schindler, D. E., 
Geoffrey, S. S., Schmid, M., Schmidt, S. R., Silow, E., Evren, S. M., Teubner, K., Verburg, P., Voutilainen, A., Watkinson, A., Williamson, C. E., and Zhang, G.: Rapid and highly variable warming of lake surface waters around the globe, Geophys. Res. Lett., 42, 10773-10781, https://doi.org/10.1002/2015GL066235, 2015.

Qi, M., Yao, X., Li, X., and Gao, Y.: A dataset of lake ice phenology in Qinghai Lake from 2000 to 2018, Science Data Bank, https://doi.org/10.11922/sciencedb.634, 2018.

Qiu, J.: China: The third pole, Nature, 454, 393-396, https://doi.org/10.1038/454393a, 2008.

Robinson, I. S., Wells, N. C., and Charnock, H.: The sea surface thermal boundary layer and its relevance to the measurement of sea surface temperature by airborne and spaceborne radiometers, Int. J. Remote Sens., 5, 19-45, https://doi.org/10.1080/01431168408948787, 1984.

Rooney, G. G. and Bornemann, F. J.: The performance of FLake in the Met Office Unified Model, Tellus, 65, 1089-1108, https://doi.org/10.3402/tellusa.v65i0.21363, 2013.

Rouse, W. R., Oswald, C. M., Binyamin, J., Blanken, P. D., Schertzer, W. M., and Spence, C.: Interannual and seasonal variability of the surface energy balance and temperature of central Great Slave Lake, J. Hydrometeorol., 4, 720-730, https://doi.org/10.1175/15257541(2003)004<0720:IASVOT>2.0.CO;2, 2003.

Salgado, R. and Le Moigne, P.: Coupling of the FLake model to the Surfex externalized surface model, Boreal Environ. Res., 15, 231-244, 2010.

Schmid, M., Hunziker, S., and Wüest, A.: Lake surface temperatures in a changing climate: A global sensitivity analysis, Climatic Change, 124, 301-315, https://doi.org/10.1007/s10584014-1087-2, 2014.

Scott, R. W. and Huff, F. A.: Impacts of the Great Lakes on regional climate conditions, J. Great Lakes Res., 22, 845-863, https://doi.org/10.1016/S0380-1330(96)71006-7, 1996.

Shen, M., Piao, S., Jeong, S.-J., Zhou, L., Zeng, Z., Ciais, P., Chen, D., Huang, M., Jin, C.-S., Li, L. Z. X., Li, Y., Myneni, R. B., Yang, K., Zhang, G., Zhang, Y., and Yao, T.: Evaporative cooling over the Tibetan Plateau induced by vegetation growth, P. Natl. Acad. Sci. USA, 112, 9299-9304, https://doi.org/10.1073/pnas.1504418112, 2015.

Stepanenko, V. M., Martynov, A., Jöhnk, K. D., Subin, Z. M., Perroud, M., Fang, X., Beyrich, F., Mironov, D., and Goyette, S.: A one-dimensional model intercomparison study of thermal regime of a shallow, turbid midlatitude lake, Geosci. Model Dev., 6, 1337-1352, https://doi.org/10.5194/gmd-6-1337-2013, 2013.

Thiery, W., Martynov, A., Darchambeau, F., Descy, J.-P., Plisnier, P.-D., Sushama, L., and van Lipzig, N. P. M.: Understanding the performance of the FLake model over two African Great Lakes, Geosci. Model Dev., 7, 317-337, https://doi.org/10.5194/gmd-7317-2014, 2014.

Tang, L., Duan, X., Kong, F., Zhang, F., Zheng, Y., Li, Z., Mei, Y., Zhao, Y., and $\mathrm{Hu}, \mathrm{S}$.: Influences of climate change on area variation of Qinghai Lake on Qinghai-Tibetan Plateau since 1980s, Sci. Rep.-UK, 8, 7331, https://doi.org/10.1038/s41598018-25683-3, 2018.

UNESCO: The Practical Salinity Scale 1978 and the International Equation of State of Seawater 1980, Technical Paper in Marine Science, 36, 1981.
Wan, Z., Zhang, Y., Zhang, Q., and Li, Z. L.: Quality assessment and validation of the MODIS global land surface temperature, Int. J. Remote. Sens., 25, 261-274, https://doi.org/10.1080/0143116031000116417, 2004.

Wang, M., Hou, J., and Lei, Y.: Classification of Tibetan lakes based on variations in seasonal lake water temperature, Chinese Sci. Bull., 59, 4847-4855, https://doi.org/10.1007/s11434-014-05888,2014

Wen, L., Lyu, S., Kirillin, G., Li, Z., and Zhao, L.: Air-lake boundary layer and performance of a simple lake parameterization scheme over the Tibetan highlands, Tellus A, 68, 31091, https://doi.org/10.3402/tellusa.v68.31091, 2016.

Weyhenmeyer, G. A., Meili, M., and Livingstone, D. M.: Nonlinear temperature response of lake ice breakup, Geophys. Res. Lett., 31, L07203, https://doi.org/10.1029/2004GL019530, 2004.

Williamson, C. E., Saros, J. E., Vincent, W. F., and Smol, J. P.: Lakes and reservoirs as sentinels, integrators, and regulators of climate change, Limnol. Oceanogr., 54, 2273-2282, https://doi.org/10.4319/lo.2009.54.6_part_2.2273, 2009.

Xu, X., Lu, C., Shi, X., and Gao, S.: World water tower: An atmospheric perspective, Geophys. Res. Lett., 35, 525-530, https://doi.org/10.1029/2008GL035867, 2008.

Yanai, M., Li, C., and Song, Z.: Seasonal heating of the Tibetan Plateau and its effects on the evolution of the Asian summer monsoon, J. Meteorol. Soc. Jpn., 70, 319-351, https://doi.org/10.2151/jmsj1965.70.1B_319, 1992.

Yang, K., He, J., Tang, W., Qin, J., and Cheng, C.: On downward shortwave and longwave radiations over high altitude regions: Observation and modeling in the Tibetan Plateau, Agr. Forest Meteorol., 150, 38-46, https://doi.org/10.1016/j.agrformet.2009.08.004, 2010.

Yang, K., Wu, H., Qin, J., Lin, C., Tang, W., and Chen Y.: Recent climate changes over the Tibetan Plateau and their impacts on energy and water cycle: A review, Global Planet. Change, 112, 79-91, https://doi.org/10.1016/j.gloplacha.2013.12.001, 2014.

Yao, X., Li, L., Zhao, J., Sun, M., Li, J., Gong, P., and An, L.: Spatial-temporal variations of lake ice phenology in the Hoh Xil region from 2000 to 2011, J. Geogr. Sci., 26, 70-82, https://doi.org/10.1007/s11442-016-1255-6, 2016.

Ye, Q., Wei, Q., Hochschild, V., and Duguay, C. R.: Integrated observations of lake ice at Nam Co on the Tibetan Plateau from 2001 to 2009, 2011 IEEE International Geoscience and Remote Sensing Symposium (IGARSS), Vancouver, BC, Canada, 24-29 July 2011, 3217-3220, 2011.

Zhang, G., Xie, H., Kang, S., Yi, D., and Ackley, S. F.: Monitoring lake level changes on the Tibetan Plateau using ICESat altimetry data (2003-2009), Remote. Sens. Environ., 115, 1733-1742, https://doi.org/10.1016/j.rse.2011.03.005, 2011.

Zhang, G., Yao, T., Xie, H., Qin, J., Ye, Q., Dai, Y., and Guo, R.: Estimating surface temperature changes of lakes in the Tibetan Plateau using MODIS LST data, J. Geophys. Res.-Atmos., 119, 8552-8567, https://doi.org/10.1002/2014JD021615, 2014a.

Zhang, G., Yao, T., Xie, H., Zhang, K., and Zhu, F.: Lakes' state and abundance across the Tibetan Plateau, Sci. Bull. (Beijing), 59, 3010-3021, https://doi.org/10.1007/s11434-014-0258-x, 2014b. 